\title{
Quantitative and Qualitative Aspects of Advanced Learners' L1 and L2 Mastery of Polysemous Words
}

\begin{abstract}
In the present investigation, 15 first-term university students were faced with forty decontextualised polysemous words in English (L2) and Swedish (L1) respectively and asked to indicate which, of a set of six meanings, adhered to the item in question (two to five of the meanings were correct). The polysemous words were of varying frequency. The investigation thus addresses the following research question:

In quantitative and qualitative terms, what knowledge do advanced students have of polysemous words in their L2 as compared to their L1?

Results show that most students have a relatively poor knowledge of polysemous words in both languages, especially in their L2. Furthermore, while the frequencies of the test items have no impact on the students' achievements, the relative frequencies of the meanings of the test items and the number of meanings of each test item stand in direct relation to whether the item is known or not in both languages.
\end{abstract}

\section{Introduction}

There are two main types of multi-meaning connections between word sense and word form: homonymy and polysemy (Alm-Arvius 1998: 56). While homonyms, such as bank (of a river) versus bank (financial institution) and bat (flying creature) versus bat (used in various sports) (Yule 1996), have separate dictionary entries, the meanings of polysemous words are found under one and the same dictionary entry. The present investigation will only focus on the latter of these two semantic relations. Polysemy is also the more frequent type of the two and is therefore more of a rule than an exception (Gyori 2002; Murphy 2004).

A great deal of research indicates that the meanings of polysemous words are stored together in a learner's mental lexicon, forming small worlds of their own. In Mackay (1966), for example, it was shown that in a context in which more than one meaning is plausible all meanings are activated subconsciously. This is also confirmed by quite a few other investigations (e.g. Foss 1970; Lackner/Garrett 1972). Even in cases where one meaning is considerably more likely than others, there appears to exist a brief moment during which all meanings are activated (Swinney 1979). The fact that the meanings of polysemous words are stored together in the mental lexicon is also the reason why it is possible to involve these types of words in word play to create comical effects. In the second episode of The Twilight Saga, for instance, one of the boys who can transform into a wolf warns his friend not to reveal trade secrets to Bella since she runs with vampires, meaning that she spends time with them. Bella jokingly comments on this using the more literal meaning of the same verb saying that you cannot run with them since they are too fast. As another example, in a show on Animal Planet two cats are desperately trying to get out of their fenced-in space. The cats are called Thelma and Louise, named after the two main characters in the movie with the same name. The movie's Thelma and Louise become, due to an unforeseen chain of events, outlaws and at the end of the movie they are faced with the choice of either surrendering

\footnotetext{
* Dr Monica Karlsson

Halmstad University

The School of Teacher Education

Box 823

30118 Halmstad

Sweden

mica.karlsson@glocalnet.net
} 
to the police or killing themselves. They choose the latter, driving off a deep cliff. Animal Planet's Thelma and Louise are finally able to get out by crawling under a chest of drawers, the host of the show saying that they were indeed in a tight squeeze, thus playing with the ambiguous meaning of the word squeeze. (For more examples see Alm-Arvius 2003: 141-143)

A polysemous word is thus a word that has 'multiple meanings which are related by extension' (Yule 1996: 121). More specifically, it is a word that 'commonly has a seemingly more basic or primary literal sense and one or more related, transferred or figurative readings' (Alm-Arvius 1998: 57). This can be exemplified by the verb run in The children came running towards us where run has a literal sense versus She did not run in the last election and Do you know how to run this machine? in which the use of run is more figurative.

The development of figurative meanings of polysemous words, referred to as 'layering' (Aitchison 2003: 154), is a language phenomenon that mainly occurs because people most commonly take already existing words and extend their meaning instead of creating new words (the law of least effort, Gyori 2002; Murphy 2004). Historically, new meanings of words have appeared because speakers could see conceptual links between the original sense and a newer sense. The verb launch, for instance, originally had the meaning wield a lance, but generalised over time and acquired the meaning throw (any object) forward with force. Nowadays the verb launch is probably more associated with rockets and ships than with lances, i.e. this newer meaning would now be considered the core meaning of the word launch. (Verspoor/Lowie 2003: 555)

\footnotetext{
'The core meaning is the one that represents the most literal sense that the word has in modern usage. This is not necessarily the same as the oldest meaning, because word meanings change over time. Nor is it necessarily the most frequent meaning, because figurative senses are sometimes the most frequent. It is the meaning accepted by native speakers as the one that is most established as literal and central.' (The New Oxford Dictionary of English (1998) foreword)
}

New meanings may be formed through, for instance, semantic extensions. In The houses had been gutted by grenades, the verb gut is based on its more literal use as seen in They gutted the deer (Verspoor/Lowie 2003:556). In many cases semantic extensions appear to begin with the human body and then move outward to other parts of the world, e.g. the foot of the mountain, the ribs of the ship and the head of the organisation. In other cases, the opposite direction can be seen, using everyday bodily behaviour to describe internal events, e.g. I see what Helen means, Peter held on to his point of view and Let us go over that plan again. (Aitchison 2003: 154) New meanings may also develop through specialisation and generalisation. An example of the former is the noun queen which originally was used to mean woman, but now refers to a particular kind of woman. An example of the latter concerns the noun grid the literal sense of which is a perforated or ridged metal plate but which may also be used to cover all networks of uniformly spaced and perpendicular lines. (Verspoor/Lowie 2003: 556) The links exemplified here 'are not limited to the ones that occur between a core sense and a noncore sense, but the senses are all interrelated, as one peripheral sense may form the base for an even more peripheral sense. However, there may not be any direct conceptual links between all peripheral senses' (Verspoor/Lowie 2003: 556, see also Lakoff 1987: 65). This means for example that there may not necessarily be a clear link between a polysemous word's core sense and its most frequent meaning.

On the whole, layering is a process that primarily appears to take place with short and comparatively frequent words (Zipf 1945), making polysemous words a very common vocabulary phenomenon. Thus, because frequent words have the most senses, learners encounter polysemous words more often than other types of words. It is therefore unfortunate that L2 knowledge of polysemous words has not been a common topic in research (Crossley et al. 2010: 578). The research that has been done in this area shows that learning the meanings of polysemous words is an exceedingly slow process (see Schmitt 1998 which is discussed in more detail in Subsection 2.2). In Bensoussan/Laufer (1984), for example, it was found that L2 learners did considerably worse on guessing the meaning of contextualised polysemous words than on guessing the meanings of other contextualised words. Research has also shown that 'learners will typically acquire the most 
frequent meaning senses before less frequent ones'. Schmitt (2010: 54) concludes by saying that it therefore 'often makes sense to do a frequency analysis not only on target words themselves, but also on their various meaning senses. This can be particularly true in acquisition studies where the researcher is interested in the depth of vocabulary knowledge as indicated by knowledge of the various meaning senses. While knowledge of the most frequent meaning sense is certainly important, knowledge of rarer meaning senses can indicate more comprehensive knowledge of a lexical item.' The effect of the frequencies of the various meaning senses will be investigated thoroughly in the result section of this article (3.2).

\section{Theoretical anchorage and previous research}

The following four subsections will offer theoretical anchorage and previous research relevant to the present study. The first subsection will explore L1 versus L2 vocabulary depth. In 2.2, the results of two longitudinal investigations will be discussed. Subsection 2.3 will deal specifically with Swedish students' knowledge and development of polysemous words. In the last subsection, a technique that appears to be a useful pedagogical tool for instructors and students when teaching and learning words with multiple meanings will be described.

\subsection{L1 and L2 vocabulary depth}

In the research literature there are two main ways of conceptualising vocabulary depth. On the one hand, words may be seen to be organised into lexical networks. Researchers approaching vocabulary depth in this way focus on how words are stored in learners' mental lexicons in relation to each other. On the other hand, words may be considered from a component perspective in which not only semantic characteristics, but also a word's orthographic, phonological, morphological, syntactic, collocational and pragmatic features are taken into account. It is only the former type which will be considered here.

Within a connectionist framework, whether it is concerned with an L1 or an L2 (although until recently, studies focusing on L2 networks have been rare (Crossley et al. 2010)), a developing vocabulary network, i.e. a network in which some items are acquired whereas others are lost, is described in terms of the strengthening and weakening of neural links or so called network nodes. Furthermore, Albrechtsen et al. (2008: 22) claim that

'[t]he many lexical entries in our L1 mental lexicon are not stored randomly, but are structured in a well-organized web with connections or pathways between the words; a structural system that enables us to retrieve words rapidly and with ease, because the access routes in the lexical store are varied and well-established'

and wonder

'[c]an the same be said about foreign language learners' mental lexicon at different stages of their interlanguage development. By nature, the L2 learner has had less exposure to the target language; so, one would naturally expect the L2 lexicon to differ from the L1 lexicon - not only in relation to size, but also in relation to the structural properties of the word store. But how different is the L2 lexicon?'

Trying to find out about differences between L1 and L2 vocabulary networks, researchers have engaged learners in so called vocabulary association tests of which there are two main types: productive association tests and receptive association tests. In the former case subjects are most commonly offered prompt words and asked to say/write the first word that springs to mind (Söderman 1993; Singleton 1999; Wolter 2001; Namei 2002 and 2004). Productive association tests can thus be said to deal primarily with the types of links seen in the mental lexicon. In receptive association tests informants are most commonly given a stimulus word (e.g. edit) and asked to indicate to which items in a set of words (e.g. arithmetic, film, pole, publishing, revise, risk, surface and text) they believe it is linked (Read 1993). Thus in such cases, researchers focus on the number of links and/or the density of links. (Another approach is to measure reaction time to different stimulus words (De Angelis 2007). This will, however, not be explored further here.) 
Interesting results have sprung from both types of testing. As for productive association testing, conclusions have been drawn in four main areas. Firstly, form-related responses have been contrasted with meaning-related responses and there are clear indications that both L1 and L2 beginners give more so called clang responses than adult L1 learners and advanced L2 learners. Young L1 and L2 learners are hence much more likely to give a word like land when offered the stimulus word hand, while adult L1 learners and advanced L2 learners are more likely to produce the word finger when faced with the same prompt word. (Meara 1978; Piper/Leicester 1980; Cohen/ Aphek 1981; Söderman 1993; Singleton 1999; Wolter 2001) Secondly, syntagmatic responses have been compared with paradigmatic responses. Most research in this area shows that whereas beginners (L1 as well as L2) tend to offer words that are linked collocationally to the stimulus word, such as the word butter as a response to the prompt word bread, more advanced learners (again both L1 and L2) give words that are linked predominately in hierarchical ways to the prompt word, such as the word animal as a response to the stimulus word $d o g$. Thirdly, prototypical responses (which can be either syntagmatic or paradigmatic), i.e. answers that a majority of informants tend to give to certain prompt words (Singleton 1999; Wilks/Meara 2002; Murphy 2003) (e.g. ice, hot, freezing and blue as responses to the stimulus word cold) have been contrasted with more infrequent responses (e.g. shoulder, hankie and dreary as responses to cold) (Albrechtsen/Haastrup/ Kristensen 2008: 33). Results of such studies show that native speakers generally produce many more prototypical responses than do non-native speakers and that advanced L2 learners produce more such responses than do low-proficiency L2 learners. This is especially interesting in view of the fact that prototypical associative links appear to "play a central role in the structuring of the mental lexicon, perhaps functioning as bridges or pointers between different parts of the net' (Albrechtsen et al. 2008: 34). Lastly, the frequency of the response word has been investigated. Research here shows that high-achievers in an L2 are not only more likely to offer prototypical answers than low-achievers as described above, but are also more likely to produce more lowfrequent responses than low-achievers (e.g. Namei 2002 and 2004). From the above, it is evident that there is a difference in the number of form-related/meaning-related, syntagmatic/paradigmatic, prototypical/non-prototypical and high-frequent/low-frequent responses given between on the one hand L1 learners and L2 learners and on the other hand advanced L2 learners and low-proficiency L2 learners. Nevertheless, Albrechtsen et al. (2008: 35) emphasise that

\footnotetext{
'[t]he whole lexicon as such cannot be described as either form-driven versus meaning-driven or syntagmatically versus paradigmatically structured. The structural properties of the lexicon will rather be determined by the language learner's degree of knowledge of the individual lexical item. In the initial phases of learning, the semantic specifications in the lexical entry are relatively weak, and we thus find that formal factors play a significant role. When dealing with less familiar vocabulary items with weaker semantic specifications mapped onto the word the more advanced learner may still rely more on the form-driven, phonological information in the lexical entry. With increased word knowledge, the words become more and more meaning-driven. Paradigmatic or syntagmatic response types will be given, but the response type will be related to the degree of word knowledge.'
}

Receptive association testing, focusing on, as mentioned above, the number and density of word links, has also produced some interesting results that help shed light on differences in the structure of the L1 and L2 lexical network. In Greidanus/Beks/Wakely (2005), for instance, native speakers clearly outperformed L2 learners in identifying association links between words. Moreover, Greidanus/Nienhuis (2001) and Greidanus et al. (2004) could show that the more advanced the L2 learners were, the more links they could identify. This difference was especially pronounced with high-frequency words. Albrechtsen et al. (2008:38) conclude that

\footnotetext{
'[n]ative speakers are able to identify a significantly higher proportion of network links than are L2 learners. In other words, the results indicate that the mental lexicon of a language learner is qualitatively different; that is, less dense than that of a native speaker. An implication of this may be that an L2 learner's retrieval paths are different as to the number of paths and their length; a fact that may well affect his ability to access words efficiently in L2 reception.'
}

When it comes to network models concerned with polysemous words, they are 
'premised on the notion that the multiple senses for a word are not contained in separate lexical entries. Such models suggest that separate entries for related word senses would be uneconomical because they would take up more storage space and would fail to capture the sense connections in the word's uses.' (Crossley et al. 2010: 576 (from Nunberg 1979; Pustejovsky 1995; Verspoor/Lowie 2003))

Instead, such lexical networks

\begin{abstract}
'allow learners to recognize meaning relationships between a word's senses because the word's senses are located within a single lexical item. This lexical item is based on the core meaning of the word and allows for semantic extensions of that core meaning to remain within the confines of that single lexical item instead of being dispersed into individual lexical items for each related sense.' (Crossley et al. 2010: 576-577 (from Langacker 2002 and Verspoor/Lowie 2003))
\end{abstract}

This tallies well with earlier research, as described in Section 1.

\title{
2.2. L2 learners' mastery of polysemous words
}

In Schmitt (1998) learners' incremental acquisition of meanings of polysemous words was investigated. The study, which is one of comparatively few in the area, included three advanced learners of English (one from India, one from Lithuania, one from Taiwan, all of whom were postgraduate male university students) and lasted for a year during which the learners' acquisition of 11 words with multiple meanings was looked into. In order to make sure that the words were encountered during the subjects' university studies, the 11 words were all picked from the University Word List (Xue/Nation 1984; Nation 1990). The words were also required to have at least three different meanings, exemplified by the test item dedicate which has four meanings: devote oneself to a good cause, address one's publication to someone, devote something to a sacred purpose and to set aside something for a particular reason. Furthermore, since the informants were advanced learners of English, some comparatively infrequent words were also included in order to ensure insights into the beginning stages of acquisition. Schmitt thus ended up with 2 relatively unknown words (brood and spur), 4 comparatively frequent words (abandon, dedicate, illuminate and suspend) and 5 that could be placed in between (circulate, convert, launch, pilot and trace).

Both the informants' receptive and productive knowledge of the test items was investigated. Information was gained in individual sessions with the subjects in which the researcher started by asking the participants to explain all of the senses they knew for each word. The senses the learners here offered spontaneously were thought to represent their receptive knowledge. When the learners could not come up with any more meanings, the researcher gave prompt words in order to elicit additional senses that the subjects had not recalled spontaneously. For example, for the test item spur, the informants were given the prompt word horse to elicit the meaning metal device worn on the heel of a boot used to guide or encourage a horse when they had not thought of this sense themselves. Meanings that were accessed in this way were thought to demonstrate the learners' productive knowledge.

The pre-test showed that there was only one of the three subjects who knew all senses of one of the 11 words tested, i.e. in all the other cases the students had only partial knowledge of the words' different senses. In fact, on average only $50 \%$ of the meanings were known. One of the informants did not know any of the senses for 5 of the words. Schmitt comments on the results saying that 'the limited state of meaning knowledge these tables paint is surprising; one might have assumed that advanced students like these would know the majority of the target words fairly well. The upshot is that advanced NNSs may have mastery over only a rather limited number of the possible meaning senses of a word, even if they are proficient enough to study in British universities' (Schmitt 1998: 295).

Six months apart, two additional tests were administered in the same way as described above. The results from these two tests show that the students' meaning knowledge remained the same for a vast majority of the 11 test items. This indicates that acquiring knowledge of the various meanings of polysemous words is indeed a slow process. On the positive side, it also means that 
students do not appear to forget meanings once they have been learned. In fact, while there was improvement in $20 \%$ of the cases in Schmitt's study, the informants only forgot about $8 \%$ of the senses they knew at the first test opportunity. This was especially true for the senses that were known productively. Moreover, of the 74 instances of progression, there was an equal number of cases in which the informants moved from receptive knowledge to productive knowledge as cases in which the subjects moved from not knowing any meaning to gaining receptive knowledge. Unsurprisingly, there were considerably fewer cases where the knowledge moved from not knowing any meaning to having productive knowledge.

In the article 'The development of polysemy and frequency use in English second language speakers' (Crossley et al. 2010), both L2 mastery (quantitative approach) and growth (qualitative approach) in the spontaneous production of words with multiple senses in spoken language were investigated. Six L2 learners between the ages of 18 and 29 (3 having Arabic as their mother tongue, 1 Japanese, 1 Korean and 1 whose native language was Spanish) were included, all of whom were enrolled in an intensive English program at an American university and starting at the lowest proficiency level among the six that were available. In addition to presenting the learners with the TOEFL test every second month to gain information about their general language development, in turn proved to be directly linked to general vocabulary knowledge (Oller 1979; Carroll 1983; Bachman et al. 1995; Shin 2005), the six subjects were, during a one-year period, interviewed every second week in order to get more specific information about their development with polysemous words. The interviewers eliciting spoken language from the informants were graduate students taking a course in second language acquisition at the same university.

In their first analysis, having a quantitative approach, Crossley et al. investigated whether there was an increase in the informants' use of frequent words. If this were the case, since frequently used vocabulary items most often have more senses than infrequently used items (Zipf 1945, see also Section 1), it would, according to the researchers, demonstrate a movement toward the use of more words with multiple meanings. This would of course also indicate an increase in the development of lexical relationships, i.e. lexical networks, in general. While the results showed that there was a clear increase in the number of words with multiple meanings during the first four months, the material also showed that, after having reached a plateau, the students' performance began to level out. This was also noticed in the Schmitt study discussed above (1998).

In their second analysis, having a qualitative approach, Crossley et al. focused on the subjects' development of the use of 6 polysemous words that were commonly produced by the informants during the sessions with the interviewers, namely know, name, place, play, think and work. Two researchers with Ph.D.s in the field of second language acquisition were asked to categorise the senses for each of the six polysemous words tested. The results showed that a majority of the informants demonstrated word sense growth for most of the words, where most progression could be seen with know and think (all subjects) and where least progression could be detected with the word name (only 2 of the 6 learners). This means that 'although learners' production of polysemous words taper off after an initial period of growth', as seen in connection with the quantitative analysis discussed above, 'the actual sense relations that L2 learners use in their discourse increase in type (more varied senses of a lexical item).' (2010: 599) The following sentence offered by one of the informants in Crossley et al.'s investigation exemplifies the use of a core sense of think commonly produced at the beginning of the one-year study (first trimester).

(1) I think he from Chicago (sense: expect or suppose)

Another core sense of think that occurred during the first trimester was consider or judge. The following sentences on the other hand contain peripheral senses of the same word, primarily produced during the second or third trimester.

(2) I have to think a little bit, because I don't, I forgot Japanese order. (sense: cogitate, second trimester)

(3) I think I talked to you about my physics teacher in high school. (sense: remember, also second trimester) 
(4) I thinking about that. I am very famous gymnastic and I imagine that I am. (sense: imagine or visualise, third trimester)

(5) I am thinking to send you to Miami because we have company for two months. (sense: intend, also third trimester)

(6) So I take maybe one month to think. I'm think I'm going to Christian. (sense: decide by pondering, again third trimester)

(7) I just think about one problem. (sense: ponder but not decide, from the last trimester)

(8) If I read book English now so I know how can they think. How can they write? (sense: dispose mind in a certain way, again from the last trimester)

Crossley et al. thus argue that 'such an increase in word sense relations is the result of learners beginning to make associations between the multiple senses available within individual lexical items. Thus, L2 learners at an early stage are able to recognize and employ semantic extensions of core word meanings. These extensions seem to appear rapidly after the fourth month of learning. After this point, word extensions seem to increase and learners seem to have both a better understanding of word sense relations and the ability to produce more senses for each individual lexical item.' (2010: 596) Put in relation to what was discussed in connection with the first analysis, this, according to Crossley et al., 'indicates that L2 learners first produce words that have the capacity for multiple word senses and thus ambiguity; however, only after the learners have acquired the core senses of the word do they begin to acquire and produce the other word senses available to that lexical entry.' (2010: 597)

\subsection{Swedish learners' mastery of polysemous words in English}

In Odefalk (2004), a term paper supervised by the present author, the aim was to investigate comparatively advanced Swedish students' mastery of polysemous words. The 57 subjects included in the study came from three different educational levels, thus enabling the researcher to investigate differences in mastery between students of various knowledge levels. 37 of the students participated in the adult educational system, 20 of whom took the A-course in English which corresponds to the first-year course of English at upper secondary school and 17 of whom took the more advanced B-level course which corresponds to second-year English in upper secondary school. Since these students took part in the adult educational system, they were of varying ages. The rest, 20 students, were first-term university students. Although a majority of these were around twenty years of age, there were a few older students included here too.

The test given to the subjects, focusing on 48 polysemous words, was divided into three main parts, each section testing increasingly more infrequent items picked randomly from Hargevik's frequency word list of spoken and written modern English (1998). 16 of the words were representative of lower secondary school level, another 16 were categorised as items learned at upper secondary school level and the remaining 16 were judged to be items typically introduced at university level. Furthermore, for each of the 48 words tested the informants were offered six decontextualised meanings in Swedish. At least two of these six meanings were correct. Also, in order to deter the students from indicating all of the meanings given, the subjects were informed that at least one of the meanings was incorrect and that points would be deducted for erroneous answers.

The incorrect alternatives were created in one of four ways. Either the incorrect meaning displayed orthographic and/or phonological similarities with the word tested. Stabilitet (=stability) and bagare (=baker), for instance, were offered as incorrect meanings of the English words ability and bag respectively. Other incorrect alternatives were translations of French words that share phonological and/or orthographic similarities with the word tested. ${ }^{1}$ As incorrect meanings for the polysemous words bag and suit, for example, the students were offered ring (from the French

1 Due to the influence of French on the English language, this was deemed appropriate. 
word bague) and överleva (which is a translation of the French verb suivre, the past participle of which looks like the English word suit) respectively. Still other incorrect meanings were based on Swedish translations of English words that have similar orthographic and/or phonological characteristics. Tillagad (=cooked) and tonåring (=teen) are examples of this kind, used as incorrect meanings for crooked and tin respectively. Lastly, some of the incorrect meanings were simply picked randomly, thus showing no real links to the meanings of the polysemous words tested.

Table 1 presents the subjects' average scores on the three test parts in Odefalk's study. As can be seen, for all three test groups the results are frequency-dependent so that the average score is highest for the most common items (Part I) and lowest for the least common items (Part III), the difference between Part I and Part III being greatest for the A-level students and smallest for the university students.

\begin{tabular}{|l|c|}
\hline & Average score \\
\hline A-level (20 students) & (total: 55) \\
\hline Part I & 24 \\
\hline Part II & 17 \\
\hline Part III & 14 \\
\hline & \\
\hline B-level students (17 students) & (total: 68 ) \\
\hline Part I & 27 \\
\hline Part II & 24 \\
\hline Part III & 18 \\
\hline & \\
\hline University level (20 students) & (total: 84 ) \\
\hline Part I & 31 \\
\hline Part II & 27 \\
\hline Part III & 25 \\
\hline
\end{tabular}

Table 1. Average scores for the three student groups tested on the three different frequency-based test parts. (Odefalk 2004: 10, 14 and 17)

In the following table, the results are put in relation to the number of correct meanings mastered by the students.

\begin{tabular}{|c|c|c|c|}
\hline Correct meanings given & Part I & Part II & Part III \\
\hline A-level (20 students) & & & \\
\hline 1 & $90 \%$ & $80 \%$ & $64 \%$ \\
\hline 2 & $56 \%$ & $40 \%$ & $32 \%$ \\
\hline 3 & $23 \%$ & $14 \%$ & $13 \%$ \\
\hline 4 & $7 \%$ & $7 \%$ & $5 \%$ \\
\hline 5 & - & - & - \\
\hline & & & \\
\hline B-level (17 students) & & & \\
\hline 1 & $92 \%$ & $90 \%$ & $73 \%$ \\
\hline 2 & $70 \%$ & $52 \%$ & $43 \%$ \\
\hline 3 & $19 \%$ & $20 \%$ & $12 \%$ \\
\hline 4 & $3 \%$ & $7 \%$ & $6 \%$ \\
\hline 5 & - & - & - \\
\hline & & & \\
\hline University level (20 students) & & & \\
\hline 1 & $99 \%$ & $92 \%$ & $84 \%$ \\
\hline 2 & $85 \%$ & $72 \%$ & $60 \%$ \\
\hline 3 & $40 \%$ & $21 \%$ & $29 \%$ \\
\hline 4 & $13 \%$ & $11 \%$ & $11 \%$ \\
\hline 5 & - & $5 \%$ & $1 \%$ \\
\hline
\end{tabular}

Table 2. Percentages of correct answers for each correct meaning for the three student groups tested. (Odefalk 2004: 11, 14 and 17) 
From Table 2, it can be seen that on all three educational levels and within all three frequencybands, an overwhelming majority knew one meaning of the polysemous words tested. However, the students' mastery appears to decrease dramatically when two or more meanings are considered. This too applies to all educational levels as well as the three frequency-bands tested, the decrease being least pronounced with the university students and most visible with the A-level students. In fact, the students from upper secondary school level only knew two meanings for about half of the words tested as compared to three quarters for the university students. Odefalk also points out that erroneous meanings that were indicated as correct senses were very often synforms, i.e. errors were induced by there being similarities in form and/or sound, as exemplified by the Swedish word lastbil (=truck), which quite a few of the students believed was one of the meanings of the polysemous word trunk, and smidighet (=agility) which some students thought was one of the meanings of the word ability $(2004: 11,15)$.

The informants in Odefalk's investigation were not only asked to indicate which of the meanings they thought were correct, but they were also told to rank their choices according to how certain they were that these actually were correct senses of the word at hand. The results of this part are shown in Table 3.

\begin{tabular}{|l|c|c|c|}
\hline & Part I & Part II & Part III \\
\hline A-level $(20$ students $)$ & & & \\
\hline $1^{\text {st }}$ & $54 \%$ & $42 \%$ & $46 \%$ \\
\hline $1^{\text {st }}, 2^{\text {nd }}$ & $28 \%$ & $12 \%$ & $17 \%$ \\
\hline $1^{\text {st }}, 2^{\text {nd }}, 3^{\text {rd }}$ & $6 \%$ & $3 \%$ & $4 \%$ \\
\hline $1^{\text {st }}, 2^{\text {nd }}, 3^{\text {rd }} 4^{\text {th }}$ & $1 \%$ & - & - \\
\hline $1^{\text {st }}, 2^{\text {nd }}, 3^{\text {rd }}, 4^{\text {th }}, 5^{\text {th }}$ & - & - & - \\
\hline & & & \\
\hline B-level $(17$ students $)$ & & & \\
\hline $1^{\text {st }}$ & $55 \%$ & $40 \%$ & $43 \%$ \\
\hline $1^{\text {st }}, 2^{\text {nd }}$ & $30 \%$ & $18 \%$ & $16 \%$ \\
\hline $1^{\text {st }}, 2^{\text {nd }}, 3^{\text {rd }}$ & $3 \%$ & $3 \%$ & $1 \%$ \\
\hline $1^{\text {st }}, 2^{\text {nd }}, 3^{\text {rd }}, 4^{\text {th }}$ & - & - & - \\
\hline $1^{\text {st }}, 2^{\text {nd }}, 3^{\text {rd }}, 4^{\text {th }}, 5^{\text {th }}$ & - & - & - \\
\hline & & & \\
\hline University level $(20 \text { students })^{\text {st }}$ & & & \\
\hline $1^{\text {st }}$ & $41 \%$ & $41 \%$ & $54 \%$ \\
\hline $1^{\text {st }}, 2^{\text {nd }}$ & $80 \%$ & $20 \%$ & $26 \%$ \\
\hline $1^{\text {st }}, 2^{\text {nd }}, 3^{\text {rd }}$ & - & - & - \\
\hline $1^{\text {st }}, 2^{\text {nd }}, 3^{\text {rd }}, 4^{\text {th }}$ & - & - & - \\
\hline $1^{\text {st }}, 2^{\text {nd }}, 3^{\text {rd }}, 4^{\text {th }}, 5^{\text {th }}$ & & $8 \%$ \\
\hline
\end{tabular}

Table 3. Percentages of correct answers for the frequency order of the polysemous words tested. (Odefalk 2004: 11, 15 and 18)

In all three groups in all three frequency-bands, the students were most correct about the item they had ranked as number one, then showing a clear decrease in certainty for item number two and three. (However, when the first, second and third meanings respectively are compared across frequency bands within the same student group, there appears in a majority of cases to be an inexplicable increase in certainty for the most infrequent items (Part III).)

Finally, the results of the students' ranking presented in Table 3 were also put in relation to the order in which the senses of the polysemous words in focus are listed in Norstedts stora engelsksvenska ordbok (1993) (Figure 1). This dictionary, like a majority of other dictionaries, lists the senses of a polysemous word according to their frequency, starting with the most frequent one. It was thus investigated whether the sense the students felt most confident about also was the most frequent sense etc. This can then also be compared to the students' results when the dictionary order of the senses was disregarded (Figure 2). 


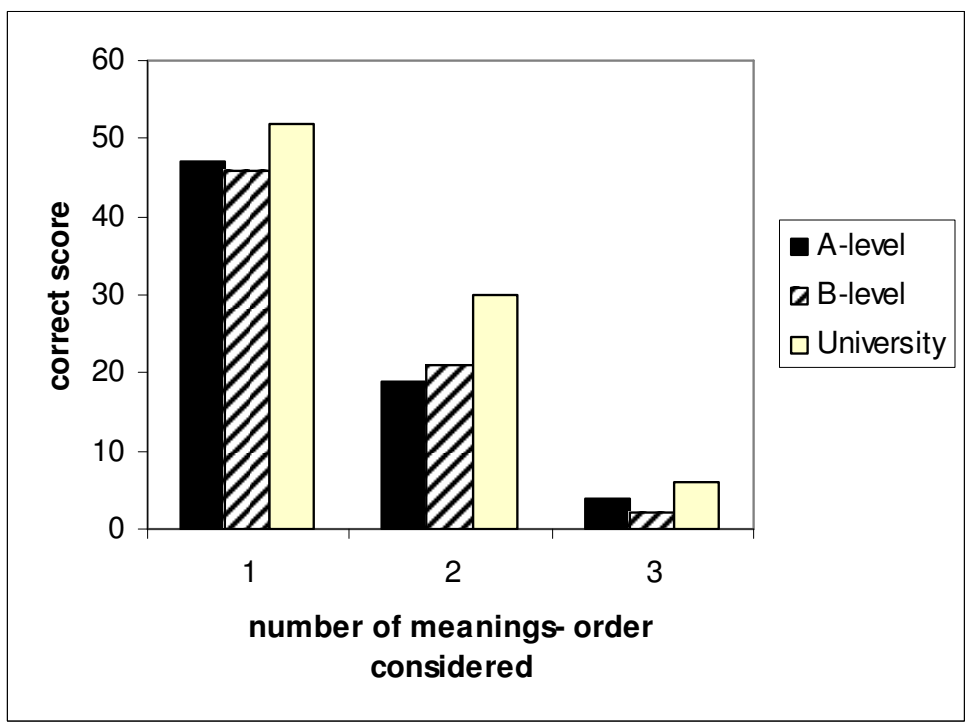

Figure 1. The relation between the students' certainty of correctness of meanings and the order of the senses in a frequency-based dictionary. (Odefalk 2004: 23)

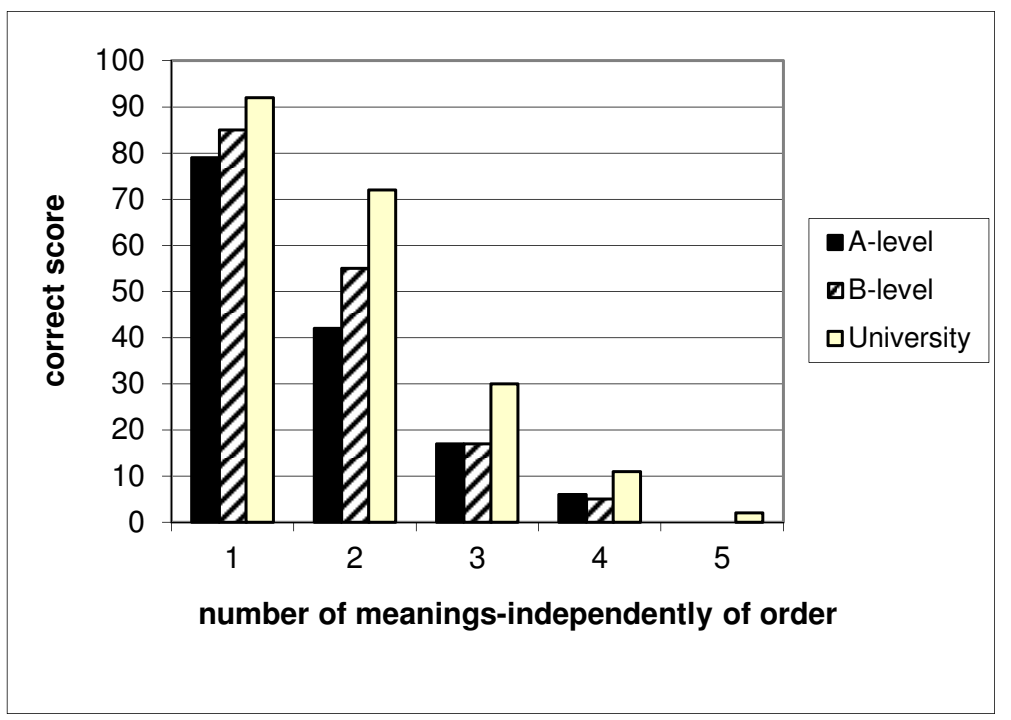

Figure 2. The students' certainty of correctness of meanings irrespective of their ranking order in a frequency-based dictionary.(Odefalk 2004: 22)

As can be seen, in all three student groups there was a correlation of approximately $50 \%$ for the sense which is listed first in Norstedts (1993) and the sense ranked as number one by the students (Figure 1), which is a lot less than when meaning-order is disregarded (Figure 2). It thus seems that frequency plays some part in whether a meaning is known or not. There is then a clear decrease for the second and third senses, down to the fourth and fifth senses for which there was no agreement at all.

\subsection{A pedagogical approach to polysemous words}

The finding that students first learn core senses of polysemous words and not until these senses have been processed move on to extended senses as discussed in Subsection 2.2 is substantiated by Verspoor/Lowie (2003). Their investigation is based on the notion that when trying to learn the various meanings of polysemous words, it might be useful to define the polysemous word with 
the help of the concept that runs through all the word's senses (Nation 2000: 51). Verspoor/Lowie's research has its foundation in on the one hand semantic networks theory (e.g. Anderson 1983; 1990) as discussed in Subsection 2.1 and on the other hand the observation that 'processing new lexical information more elaborately will lead to higher retention than by processing new lexical information less elaborately' Hulstijn (2000: 270).

In Verspoor/Lowie, it was examined whether supplying informants with the core sense of a polysemous word as compared to noncore word senses would help L2 learners figuring out the more peripheral meanings of that word. In addition, Verspoor/Lowie also investigated whether information about core word meanings improved long-term retention of the more peripheral senses. As described by the process of layering discussed earlier, it should here be noted that core meaning does not necessarily refer to the most frequent meaning.

Verspoor/Lowie (2003) built on three pilot studies. In the first one (Verspoor 1997), Dutch learners of English were offered the core meanings (in context) of previously unknown polysemous words and were asked to guess the meaning of a more figurative sense of the same word (again presented in a context). Even though the results were not statistically confirmed, a positive effect was seen on retention. The second pilot study (Rijpma 1999) investigated differences in correctness in guessing and retention when a core sense, a figurative sense or no sense was provided. The results showed clearly that the subjects' degree of accuracy in guessing the meaning as well as their retention were at their best when they had been offered a contextualised core sense. In the third pilot study (Lowie/Verspoor 2001), it could also be shown that offering a non-corebased sense made the informants less likely to remember the item in question than when providing them with a core-based sense.

The Verspoor/Lowie study from 2003 included 78 Dutch students, all of whom had at least three years of English and were taking part in a pre-university course. The subjects were divided into two groups and each group was tested three times. The polysemous words chosen to be tested adhered to two main criteria. Firstly, each had to have at least three different senses: a core sense (referred to as S1), a figurative sense (S2) and a third even more figurative sense (S3). Secondly, only items in which the meaning extensions were clearly chained to each other so that S1 had given risen to S2, S2 had given rise to S3 etc, were included. The polysemous word bulge, included in the Verspoor/Lowie study, is here given as an example.

(9) The bulge under his armpit suggested he was carrying a gun. (S1)

(10) After the war there was a bulge in the birth rate. (S2)

(11) A breakaway dunk by Raheed Wallace ended a 12-0 run by the Bullets that gave them their 5-point bulge. (S3)

Native speakers were involved to make sure that the second criterion was abided by. This selection process left the researchers with a total of 18 polysemous words (boost, grapple, bulge, skim, taut, shatter, nudge, rake, cog, nugget, gut, hoot, forge, peg, sprawl, smother, perennial and spawn), the core senses of which all deal with everyday concepts. Furthermore, all the test items were presented to the informants in sentence contexts taken from the New York Times.

In the first test, also referred to as the guessing test, both groups of students were faced with 18 sentence pairs. In each pair, one sentence was used as a cue while the other one included the test item, a figurative sense (S2), for which the subjects were asked to guess the meaning and provide a correct Dutch translation. Whereas Group 1 was prompted by sentences that contained core senses (S1) and its literal translation into Dutch, Group 2 was prompted by another figurative sense (S3) and its Dutch counterpart. Immediately after the test, the subjects were asked to memorise the correct translation of the figurative sense they had just been tested on. They were also asked if they could see any links between the different senses. The results of this test showed clearly that providing students with core senses yields higher correctness scores than prompting them with a non-core sense. It thus appears that knowing the core meaning of a polysemous word 
will help learners form meaningful links between the word's core sense and peripheral sense/s, thus enabling them to comprehend the figurative sense/s more easily.

The second test, an unannounced short-term retention test, took place immediately after the students had had a class unrelated to the subject at hand. This test also consisted of 18 sentence pairs, all of which included the same target words with focus on the S2 sense which was dealt with in the first test, but now appearing in a different order and in a different context. Again the informants were asked to give the Dutch equivalent of the S2 sense tested. The results of this test showed that short-term retention was high irrespective of whether the subjects had been provided with a core meaning (S1) or a more peripheral meaning (S3), the mean score only being marginally better for the former situation.

Lastly, two to three weeks later, both student groups were given the third test which was identical to the second test described above. Here the results showed a significant difference in mean score depending on whether the informants had been provided with a core sense or a peripheral sense, the former being by far the more beneficial of the two.

An obvious additional problem when faced with polysemous words in an L2 is that the links between peripheral senses might be unclear because the core sense in the L2 has not developed figurative senses similar to those in the L1, i.e. in many cases there is simply not a one-to-one relation between the existing peripheral senses. In the Verspoor/Lowie study, there was a clear difference in result for those senses that did not have any direct counterparts in the students' L1 and those that did. For taut, perennial and spawn, which in Dutch do not have meaning extensions similar to the ones seen in English, the translation of the S3 sense being quite different from the translation of the S2 sense, the students scored comparatively high. In contrast, for the test items cog, sprawl and grapple, for example, for which the meaning extensions in Dutch are rather similar to the ones seen in English, i.e. the translation of the $\mathrm{S} 3$ sense is rather similar to the translation of the S2 sense, the students scored comparatively poorly. This means that if the meaning extensions in the L2 are essentially the same as in the student's L1, it is not so important for retention which of the two peripheral senses is introduced first.

Verspoor/Lowie sum up by saying that L2 learners can 'benefit from a brief introduction into the way that the different senses of a polysemous word may be related to each other and to a core sense, so that they can discover meaningful links among the various senses. This knowledge can be practised in classroom and textbook exercises in which students are to guess a nonliteral sense of a suitable polysemous word from a context, but with a core sense given as an additional cue. Eventually, students should realize that finding the core sense and its meaning relationship with the other senses is a useful strategy in learning vocabulary and then should apply this strategy when they look words up in dictionaries on their own. An improved insight into the polysemous nature of words should make learners aware of the "dangers" of attaching only one meaning to a particular word form' and the researchers continue by saying that their 'findings would suggest that this approach not only should help students to understand the "imagery" of the more peripheral senses better but would also help them to remember them better'. (2003: 570)

Advice on how to teach polysemous words can, for example, also be found in Thornbury (2002) and Nation (2008). In both cases, the focus is on discussing core sense.

\section{The present study}

\subsection{The informants and the tests}

In the present investigation, 15 first-term university students were faced with an equal number of decontextualised polysemous words in English (L2) and Swedish (L1) respectively and asked to indicate which, of a set of six meanings, adhered to the item in question (two to five of the meanings were correct). (There were 12 female and 3 male students, 10 of whom were in their late teens or early 20 s, 4 in their late 20 s and 149 -year old.) The polysemous words were of varying frequency. The investigation thus addresses the following research question: 
In quantitative and qualitative terms, what knowledge do advanced students have of polysemous words in their L2 as compared to their L1?

Also, one native speaker, a 33-year old male studying within the Swedish educational system (second year) to become an upper secondary teacher of English, was used as a point of reference for the L2 test.

In both languages, 40 words with multiple meanings, based on the BNC and Språkbanken (a corpus of Swedish texts) respectively, were tested. The items were presented to the students in order of frequency, starting with the most frequent polysemous word (which on the English test was the word board) and ending with the least frequent item (on the English test the word brood). With a short break in between, the English test preceded the Swedish one and in both cases the students were able to sit with each test as long as they liked, i.e. no time constraints what so ever were put on either test. Furthermore, whereas the English test items were picked on a random basis from Norstedts engelska ordbok: Engelsk-svensk/svensk-engelsk. (CD-Rom version), the Swedish words were picked, also randomly, from Stora synonymordboken (Strömberg 1979 and 1998). Each of the words tested was awarded 1 point only when all the correct meanings were offered and none of the incorrect meanings were indicated. The reason for this rather harsh scoring system was to ensure that the students realised that it would not help to play safe by indicating all of the senses given. As in Odefalk (2004) described earlier, the students were faced with 6 alternative meanings (decontextualised) for each polysemous word, between 2 and 5 of which were correct. The table below gives an overview of the number of correct meanings for the words tested in each language and the distribution of nouns, verbs and adjectives. As the reader can see, there is not total agreement between the two tests. Here the present author thought that it was more important to prioritise the choice of polysemous words, the meanings that were to be tested and what incorrect senses could be created.

\begin{tabular}{|c|c|c|c|c|c|}
\hline & 2 senses & 3 senses & 4 senses & 5 senses & Total \\
\hline English test & $\begin{array}{c}14 \\
\text { (9 nouns; } \\
3 \text { verbs; } \\
2 \text { adjectives) }\end{array}$ & $\begin{array}{c}11 \\
\text { (5 nouns; } \\
4 \text { verbs; } \\
2 \text { adjectives) }\end{array}$ & $\begin{array}{c}13 \\
\text { (10 nouns; } \\
3 \text { adjectives) }\end{array}$ & $\begin{array}{c}2 \\
(2 \text { verbs) }\end{array}$ & $\begin{array}{c}40 \\
\text { (24 nouns; } \\
9 \text { verbs; } \\
7 \text { adjectives) }\end{array}$ \\
\hline Swedish test & $\begin{array}{c}12 \\
\text { (6 nouns; } \\
3 \text { verbs; } \\
3 \text { adjectives) }\end{array}$ & $\begin{array}{c}13 \\
\text { (3 nouns; } \\
6 \text { verbs; } \\
4 \text { adjectives) }\end{array}$ & $\begin{array}{c}12 \\
\text { (7 nouns; } \\
2 \text { verbs; } \\
3 \text { adjectives) }\end{array}$ & $\begin{array}{c}3 \\
\text { (1 noun; } \\
2 \text { verbs) }\end{array}$ & $\begin{array}{c}40 \\
\text { (17 nouns; } \\
13 \text { verbs; } \\
10 \text { adjectives) }\end{array}$ \\
\hline
\end{tabular}

Table 4. The number of senses and the distribution of word classes among the polysemous words tested in the present study

The correct alternatives were for the English test items based on Norstedts engelska ordbok: Engelsk-svensk/svensk-engelsk (CD-Rom version), which, as mentioned before, lists meanings of polysemous words in order of frequency. The meaning referred to as meaning 1 in the result section will thus in each case be more frequent than meaning 2, meaning 2 more frequent than meaning 3 etc. For the Swedish meanings Svenska Akademiens Ordlista (online) and Norstedts engelska ordbok: Engelsk-svensk/svensk-engelsk (CD-Rom version) were used. Since a clear categorisation according to frequency could not always be attained for the items chosen, the ordering of the senses is here slightly more unreliable.

As for the creation of incorrect senses on the English test, Odefalk's approach was again adhered to. Thus, some of the invented incorrect meanings showed orthographic and/or phonological similarities with the word tested. Other incorrect meanings were Swedish translations of either English or French words that also reminded orthographically and/or phonologically of the English word tested. For examples of these kinds of incorrect meanings, please go to the description of the Odefalk study. A fourth group of incorrect meanings were randomly picked senses that had 
no real connection to the word tested. The incorrect alternatives on the Swedish test were created in five different ways. Just as in the English material, some incorrect alternatives were meanings of words that phonologically and/or orthographically reminded of the polysemous word in question. Other incorrect alternatives were based on the fact that the tested word had a morphological make-up that could easily be perceived as having a very different meaning. For the test item remiss meaning referral, for example, the erroneous alternative andra missen (the second miss) was given. Others still were based on translations of English words that are phonologically and/or orthographically similar to the Swedish test word. For the polysemous word koloni meaning colony, for instance, the erroneous alternative tjocktarm (i.e. colon (part of your body)) was offered. A fourth category of incorrect alternatives consisted of senses of the antonym of the polysemous word in question. Lastly, just as in the English material, there were some incorrect alternatives that had no obvious link to the word tested.

(12) and (13) below offer two examples of the polysemous words and the senses given as possible correct answers used on the English test in the present investigation. (Definitions of the correct Swedish alternatives, all taken from Longman dictionary of contemporary English (1987), can be found in the Appendix. These definitions were also used on the test offered to the native speaker.) While only two of the meanings offered were correct for test item 26 (vocabulary meaning both ordlista (=a list of words, usually in an alphabetical order and with explanations of their meanings) and ordförråd (=words known, learnt, used, etc.), four of the offered senses were correct for test item 1 (board meaning bräda (=a long thin flat piece of wood), styrelse (=an official group that has responsibility for particular organization or activity), anslagstavla ( $=$ a flat piece of hard material used to put or write things on) and kost (=(the cost of) meals). (All the polysemous words tested in the present investigation are listed in Tables 7 (English items) and 8 (Swedish items).)
(12) vocabulary
a) vokal
d) fallenhet
b) sång (på skiva)
e) kupong
c) ordlista
f) ordförråd
(13) board
a) bord
d) jord
b) bräda
e) anslagstavla
c) styrelse
f) kost

On both tests, the students were also requested to give information as to what degree they on the one hand thought they knew the polysemous word and on the other hand to what extent they were certain of the meanings they had indicated to be correct. This is illustrated in (14) below (test item 4, for which three of the meanings offered were correct: vikt (=the heaviness of something), brevpress (=a piece of heavy material used to put on different type of paper to make it lie still) and börda (=(something that causes) a feeling of worry or anxiety)). (Definitions of the correct Swedish alternatives can again be seen in the Appendix. Here too the correct alternatives of the Swedish test items can be found.)
(14) weight
$\square$ I don't know this English word.
$\square$ I think I know this English word.

a) väntan

d) brevpress

c) vikt

e) börda

f) syn 
I think I am sure about the following one/s:

I am sure about the following one/s:

Even though it was emphasised in the instructions to the students that knowing a polysemous word means knowing all its different senses, it is, as will be seen in the result section, questionable if the students really understood the scope of the information they were asked to give concerning the extent of their knowledge of the polysemous words.

The students were also asked to evaluate the difficulty level of the test at hand, the options being 'very easy', 'easy', 'average', 'difficult' and 'very difficult'.

Lastly, the English and Swedish corpora used in the present study differ as to size. As can be seen in Table 5, the total frequency of the English test items is higher than the total frequency in the Swedish material. Thus, from a frequency perspective, the English test can be regarded as somewhat easier than the corresponding Swedish one. Furthermore, as shown in Table 4, the two tests also differ slightly as to the number of nouns, verbs and adjectives included. While, on the English test, there were 24 nouns, 9 verbs and 7 adjectives, the distribution on the Swedish test was 18 nouns, 12 verbs and 10 adjectives. Since nouns usually form more links with other words than verbs and especially adjectives, they may be considered a somewhat easier type of word to deal with than the other two (Nation 2001: 261). The English test may thus, in this respect too, be regarded as less difficult than the Swedish one.

\begin{tabular}{|c|c|c|}
\hline \multirow{2}{*}{ CORPUS } & \multicolumn{2}{|c|}{ PART A } \\
\cline { 2 - 3 } & $\begin{array}{c}\text { POLYSEMOUS WORDS } \\
\text { frequent } \\
\text { item }\end{array}$ & Total \\
\hline English corpus & $0.0139 \%$ & $0.1100 \%$ \\
\hline Swedish corpus & $0.0142 \%$ & $0.0418 \%$ \\
\hline
\end{tabular}

Table 5. A comparison between the corpora used

\subsection{Results and discussion}

Table 6 shows the students' results.

\begin{tabular}{||l|c|c||}
\hline \multirow{2}{*}{ STUDENTS } & \multicolumn{2}{|c|}{$\begin{array}{c}\text { POLYSEMOUS WORDS } \\
\text { (40 ITEMS) }\end{array}$} \\
\cline { 2 - 3 } & mean & $\begin{array}{c}\text { standard } \\
\text { deviation }\end{array}$ \\
\hline $\begin{array}{l}\text { Native speaker } \\
\text { of English }\end{array}$ & $21.0^{2}$ & - \\
\hline $\begin{array}{l}\text { Swedish students - } \\
\text { English test }\end{array}$ & 13.2 & 4.1266 \\
\hline $\begin{array}{l}\text { Swedish students - } \\
\text { Swedish test }\end{array}$ & 15.3 & 3.8484 \\
\hline
\end{tabular}

Table 6. The students' results

2 Due to a construction error, polysemous word number 27 (needle) contained five correct answers for the native speaker, not four as for the Swedish learners. 
As in Schmitt (1998) discussed in Subsection 2.2, the students in the present investigation did very poorly on the English test, only a mean score of 13.2 correct answers out of 40 possible $(=33.0 \%)$ was achieved. (It is interesting to note though that one of the informants actually outperformed the native speaker by one point (see Table 14 which shows the students' individual results on the English test).) This can be compared to the results seen in Odefalk in which the A-level students got a mean score of 18.3 out of $48(=38.2 \%)$, the B-level students 22.7 out of $48(=47.2 \%)$ and the university students, comparable to the present subjects, a mean score of 28.0 out of $48(=58.3 \%)$. It must, however, be pointed out that the scoring system used in Odefalk was considerably more lenient than in the present investigation where the students had to indicate all correct meanings and none of the incorrect ones in order to receive one point. As seen in most research on polysemous words, the results here thus indicate that acquiring senses of words with multiple meanings is a laborious task that takes a great deal of time, even for advanced students such as the ones included in the present study. Also, as evidenced by the result of on the one hand the native speaker of English (21.0 out of $40(=52.5 \%)$ ) and on the other hand the informants' mean on the Swedish test $(15.3$ out of $40(=38.2 \%))$, it is safe to say that even in an L1 learning meanings of polysemous words takes a great deal of time and effort. (Part of the reason for the subjects' low mean on the Swedish test in relation to the English test may of course be due to the fact that the Swedish test items were on the whole slightly more infrequent than the English ones (see Table 5).) That the students indeed did do better in their first language than in their L2 is, however, substantiated both by the mean score and the difference in standard deviation.

It here also needs to be pointed out that it is of course much more difficult to give correct meanings of decontextualised words than of items that are offered in supportive contexts, even though, as pointed out in Section 1, context appears to help less with the meanings of polysemous words than with the meanings of other types of vocabulary items (Bensoussan/Laufer 1984). In addition to the density of unknown words in text (Sternberg 1987), which research has shown should not exceed 2-5\% for successful inferencing (Nation 2001), there are a number of other so called mediating variables (Jenkins/Dixon 1983) that can strengthen a learner's chances of guessing the meaning of a contextualised word (Nation 2001: 243, 245). The most useful information appears to come from clues in the immediate context, i.e. within the same sentence as the unknown word itself (Chihara et al. 1977; Leys et al. 1983; Rye 1985). Not only is the presence of clues important for successful inferencing (Nation 2001), but also the number of relevant clues (Nation 2001), their proximity and explicitness (Carnine et al. 1984). The absence of such mediating variables in the present study may of course also help explain the informants' low scores in both languages. (For more examples of mediating variables, go to Nation (2001).)

Table 7 shows the students' evaluation of the difficulty level of the tests.

\begin{tabular}{|l|c|c|c|c|c|}
\hline \multicolumn{1}{|c|}{ STUDENTS } & \multicolumn{5}{|c|}{ POLYSEMOUS WORDS } \\
\hline $\begin{array}{l}\text { Native speaker } \\
\text { of English }\end{array}$ & ve & e & av & d & vd \\
\cline { 2 - 7 } & - & 1 & - & - & - \\
\hline $\begin{array}{l}\text { Swedish students - } \\
\text { English test }\end{array}$ & ve & e & av & d & vd \\
\cline { 2 - 7 } $\begin{array}{l}\text { Swedish students }- \\
\text { Swedish test }\end{array}$ & ve & e & av & d & vd \\
\cline { 2 - 7 } & - & 4 & 9 & 1 & 1 \\
\hline
\end{tabular}

Table 7. The students' evaluation of the difficulty level of Part A - polysemous words. (ve=very easy, $\mathrm{e}=$ easy, av=average, $\mathrm{d}=$ difficult, $\mathrm{vd}=$ =very difficult)

As can be seen, both the native speaker and the Swedish informants (on the English test as well as on the test in their native language) appear to be overly confident in their knowledge of the items 
at hand, not realising the number of meanings a polysemous word may have. In fact, a majority of the Swedish students indicated that they thought the test to be either 'average' ( 9 students) or even 'easy' ( 3 students), only 3 subjects thinking that polysemous words were 'difficult' ( 2 students) or 'very difficult' ( 1 student). Unsurprisingly, this over-confidence is even more pronounced in the students' mother tongue, where 13 students believed the test to be either 'easy' (4 students) or 'average' ( 9 students). Here only 2 of the participants thought the test to be 'difficult' ( 1 student) or 'very difficult' (consequently also 1 student). As stated above, the native speaker also misjudged his knowledge, indicating that the test was 'easy', although he only knew all the senses sought for in 21 out of 40 cases.

In Figures 3 (English test items) and 4 (Swedish test items) the total number of correct answers for the 40 polysemous words tested in each language is shown. The reader is reminded that the items were presented to the informants according to frequency, starting with the most common word, i.e. test item 1 is the most common polysemous word of the ones tested, test item 2 is the second most common etc. Also, the results indicated in red in Figure 3 are words that are found on West's service list (1953) of 2,000 frequent head words. No corresponding list could be found for Swedish words.

When studying Figures 3 and 4, it can safely be assumed that the frequencies of these polysemous words play little or no role in whether the senses of the words are known or not. This holds true for both the students' L2 as well as their L1. This is substantiated further by the fact that the words tested have a wide frequency span, the two most frequent items board and börja occurring 13,873 and 9,923 times respectively and the two most infrequent items brood and tetig only occurring 5 and 4 times respectively. (For the English words this is also corroborated by the fact that it does not seem to matter whether the BNC or West's service list is considered. In fact, quite a few of the words tested that received no points are found on West's service list (board, sheet, square, grace, needle, rude, trunk and advance).) While for instance then the English test items 2 (director, 1 point (also included on West's service list as a common word)), 5 (domestic, also 1 point) and 9 (keen, 2 points) which are comparatively common words received low scores, relatively infrequent test items such as vocabulary (item 26,12 points), nail (item 35,14 points) and crooked (item 36, 15 points) received high scores. This result does not tally with what was seen in Odefalk's investigation (see Tables 1 and 2) where frequency had a clear impact on the students' mastery. One reason for this difference in result may be that that the words tested in Odefalk might have had an even greater frequency span and that the boundaries between the three frequency bands included in her study were clearly delimited.

Not surprisingly, the success or non-success with which the students are able to indicate the correct meanings of the polysemous words rather seem to have to do with the number of meanings sought. This will be discussed in the paragraphs that follow. 


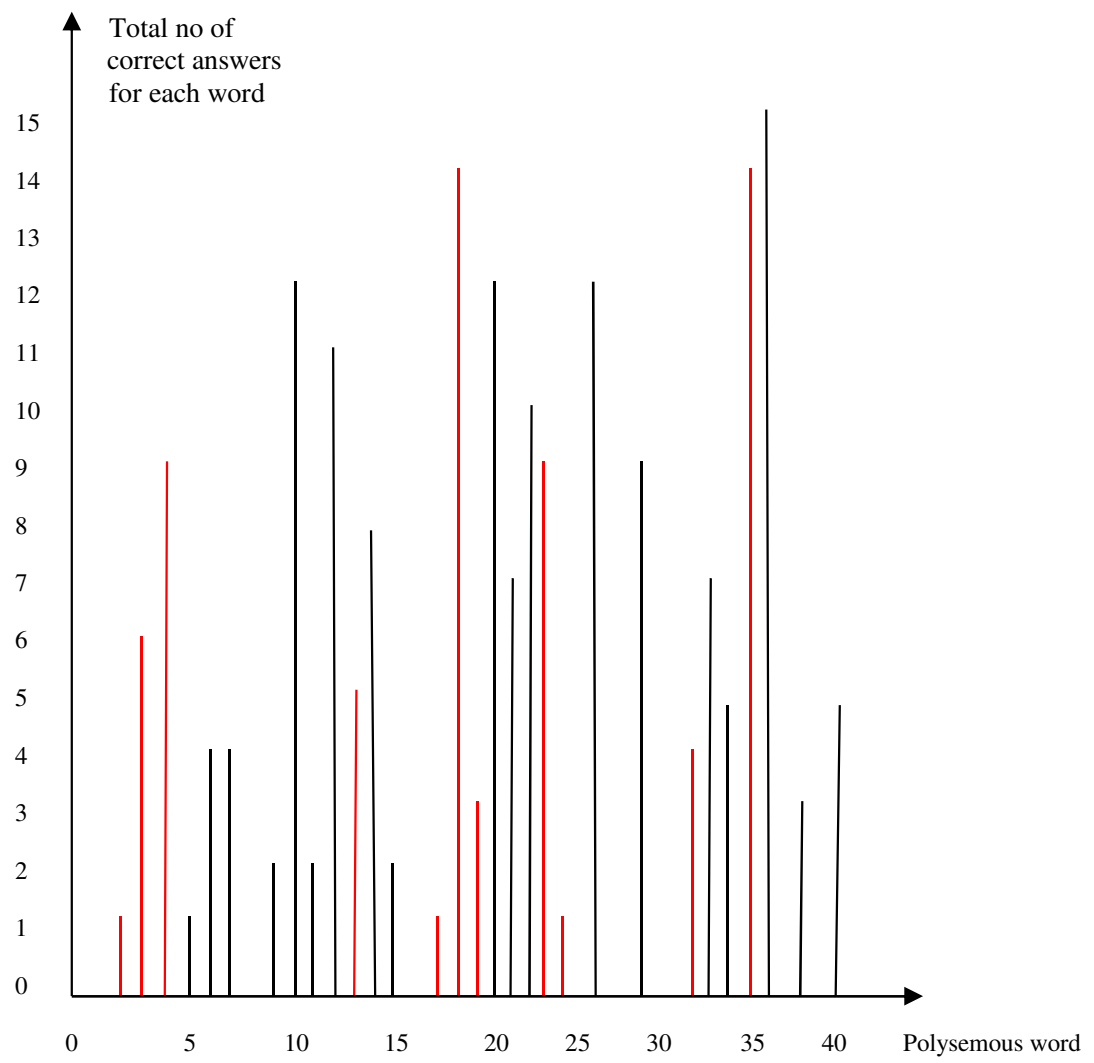

Figure 3. The total number of correct answers for each of the 40 polysemous words on the English test

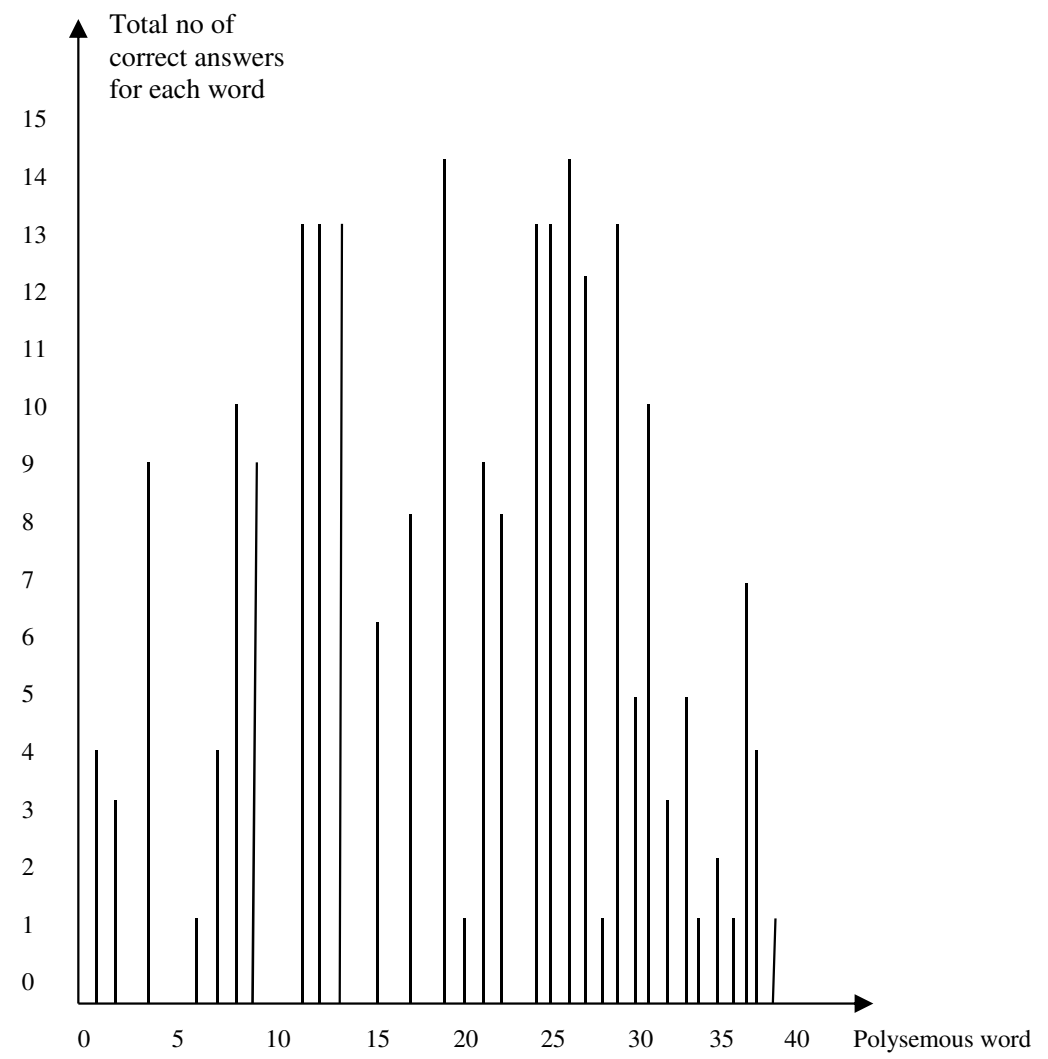

Figure 4. The total number of correct answers for each of the 40 polysemous words on the Swedish test 
In Tables 8 (the English test) and 9 (the Swedish test), the results for words for which students gave accurate answers are presented, starting with the word that most of the students knew (on the English test: crooked (15 points)). (When more than one test item received the same score, the polysemous word for which the informants showed the greatest accuracy in their self-evaluation is placed first.) Also, the items found on West's service list (1953) are indicated in red. For example, for test item 12 (journal), i.e. the twelfth most common item, 11 of the 15 students knew the two meanings sought and did not indicate any meanings that were incorrect. 8 of the students (indicated in grey since they were in the majority) were absolutely sure that they knew the word (column S under information, polysemous word), while 3 students showed less certainty indicating that they only thought they knew the word journal (column TK under information, polysemous word). When it comes to the different senses of this word, 8 students indicated that they were sure of the most frequent meaning (under MEANINGS/SURE, first column and indicated in grey since they were in the majority) and 2 that they thought they were sure (under MEANINGS/THINK SURE, first column). As for the second most frequent sense tested, 9 of the students were certain that they knew this (under MEANINGS/SURE, second column and again coloured in grey since these were in the majority), while only 1 indicated a lesser degree of certainty (under MEANINGS/THINK SURE, second column). Table 9 showing the students' results on the Swedish test should be interpreted in exactly the same way.

On the English test only 3 of the 40 polysemous words tested received the three highest scores (15 points: 1 item; 14 points: 2 items; 13 points: no items) as compared to 8 out of 40 items on the Swedish test (15 points: no items (!); 14 points: 2 items; 13 points: 6 items). Even if the words for which most of the students ( 8 out of 15) knew all the correct senses are considered, only 12 of the 40 words would be included on the English test (from crooked down to and including exclusive). This can be compared to 16 of 40 on the Swedish test (from greppa down to and including fiction). Similarly, of the 40 words tested as many as 17 received 0 (10 words), 1 (4 words) or 2 points ( 3 words) only on the English test, the corresponding figure for the Swedish test items being as high as 15 (0: 8 items; 1: 6 items; $2: 1$ item). (Items for which informants were unable to offer all the right senses and/or gave incorrect senses for will be explored in more detail in connection with Tables 10 and 11.) As expected, these results indicate that the students have acquired more depth in their knowledge of polysemous words in their native language than in their L2. However, as discussed in connection with the students' mean scores (see Table 6), the difference between their mastery in their L2 as compared to their L1 is not as great as one would have assumed, indicating the difficult nature of network building in general. The comparative lack of depth in the students' L2 as well as in their L1 is substantiated even further by the fact that there is a concentration of polysemous words for which only two meanings were sought at the top of the tables and a similar concentration of items for which the students had to know four or five senses at the bottom of the tables. In fact, while the 7 top-most items on the English test and the 6 top-most words on the Swedish test involve polysemous words for which only two senses were sought, 9 of the 10 items receiving no correct answers on the English test and 6 of 8 items on the Swedish test involve polysemous words for which either four or five senses were sought. The same tendency can be seen with the native speaker. Of the 19 words for which he was unable to offer all the right meanings, 6 (board, square, needle, rude, trunk and advance) were words for which 4 or 5 meanings were sought. It is also interesting to note that all these words were items for which none of the Swedish informants received points.

As can be seen from the above, the lack of vocabulary depth is, not surprisingly, especially pronounced in the students' L2. Nevertheless, in their L1 as well as in their L2, the informants seem to be confident concerning their knowledge, indicating for an overwhelming majority of the test items that they are certain that they know the polysemous words and their senses. For the various meanings, this is especially true for the first and second ones (all indicated in grey in the Tables 8 and 9$)$. 
Lastly, it is also interesting to note that word class affiliation does not seem to play any major role in whether the senses of a word are known or not in either language, nouns, verbs and adjectives receiving both high and low scores. Again, it is rather the number of meanings sought which is the determining factor as to whether the students are successful or not.

\begin{tabular}{|c|c|c|c|c|c|c|c|c|c|c|c|c|c|c|c|c|c|c|c|}
\hline \multirow{3}{*}{ NO } & \multirow{2}{*}{\multicolumn{3}{|c|}{$\begin{array}{l}\text { POLYSEMOUS } \\
\text { WORD (INFO) }\end{array}$}} & \multirow{3}{*}{$\begin{array}{c}\text { WORD } \\
\text { (NO OF CORRECT } \\
\text { ANSWERS) }\end{array}$} & \multicolumn{15}{|c|}{ "MEANINGS } \\
\hline & & & & & \multicolumn{5}{|c|}{ SURE } & \multicolumn{5}{|c|}{ THINK SURE } & \multicolumn{5}{|c|}{ NOT SURE } \\
\hline & $\mathrm{S}$ & TK & NK & & 1 & 2 & 3 & 4 & 5 & 1 & 2 & 3 & 4 & 5 & 1 & 2 & 3 & 4 & 5 \\
\hline A36 & 6 & 7 & $1(1)$ & crooked (15) & 12 & 9 & & & & 2 & 3 & & & & & 2 & & & \\
\hline A18 & 8 & 6 & & comfort (14) (n) & 13 & 13 & & & & & & & & & & & & & \\
\hline A35 & 12 & 1 & $1(1)$ & nail (14) (n) & 13 & 13 & & & & & & & & & & & & & \\
\hline A20 & 8 & 4 & & expand (12) & 11 & 8 & & & & & 2 & & & & & 1 & & & \\
\hline A10 & 8 & 4 & & intelligence (12) & 10 & 8 & & & & 1 & 2 & & & & & 1 & & & \\
\hline A26 & 9 & 3 & & vocabulary (12) & 6 & 9 & & & & 4 & 2 & & & & 1 & & & & \\
\hline A12 & 8 & 3 & & journal (11) & 8 & 9 & & & & 2 & 1 & & & & & & & & \\
\hline A22 & 8 & 1 & $1(1)$ & withdraw (10) & 5 & 7 & 7 & & & 4 & 1 & 1 & & & & 1 & 1 & & \\
\hline A4 & 9 & & & weight (9) & 9 & 7 & 4 & & & & 2 & & & & & & 5 & & \\
\hline A29 & 7 & 1 & $1(1)$ & torch (9) (n) & 8 & 6 & & & & & 2 & & & & & & & & \\
\hline A23 & 7 & 2 & & support (9) (v) & 7 & 8 & 6 & & & 2 & 1 & 3 & & & & & & & \\
\hline A14 & 5 & 3 & & exclusive (8) & 6 & 6 & & & & 2 & 1 & & & & & 1 & & & \\
\hline A33 & 5 & 2 & & expose (7) & 7 & 6 & 2 & & & & 1 & 1 & & & & & 4 & & \\
\hline A21 & 4 & 3 & & pursuit (7) & 5 & 2 & & & & 1 & 4 & & & & 1 & 1 & & & \\
\hline A3 & 5 & 1 & & ability (6) & 6 & 4 & & & & & 2 & & & & & & & & \\
\hline A13 & 3 & 2 & & resignation (5) & 5 & 4 & & & & & 1 & & & & & & & & \\
\hline A34 & 1 & 4 & & suppress (5) & 3 & 2 & 1 & & & 1 & & 1 & & & 1 & 3 & 3 & & \\
\hline A40 & 2 & 3 & & brood $(5)(v)$ & 1 & 4 & & & & 2 & 1 & & & & 2 & & & & \\
\hline A7 & 2 & 2 & & credit (4) (n) & 4 & 4 & 3 & 3 & & & & & & & & & 1 & 1 & \\
\hline A6 & 4 & & & administration (4) & 4 & 3 & 2 & 3 & & & 1 & 1 & & & & & 1 & 1 & \\
\hline A32 & & 1 & $2(2)$ & idle (4) (adj) & 2 & 1 & 1 & & & & & 1 & & & 2 & 3 & 2 & & \\
\hline A19 & 3 & & & dealer (3) & 2 & 1 & 3 & 3 & & 1 & 2 & & & & & & & & \\
\hline A38 & 1 & & $2(2)$ & haul (3) (v) & 1 & 1 & & & & & & & & & 2 & 2 & & & \\
\hline A11 & 1 & 1 & & peak (2) (n) & 2 & 2 & 2 & & & & & & & & & & & & \\
\hline A15 & 1 & 1 & & wire (2) (n) & 2 & & & & & & 1 & 1 & & & & 1 & $\overline{1}$ & & \\
\hline A9 & 2 & & & keen $(2)$ & 1 & 1 & 1 & 2 & & & & & & & 1 & 1 & 1 & & \\
\hline A5 & 1 & & & domestic (1) & 1 & 1 & 1 & 1 & & & & & & & & & & & \\
\hline $\mathrm{A} 2$ & 1 & & & director (1) & 1 & 1 & 1 & & & & & & 1 & & & & & & \\
\hline A17 & 1 & & & suit (1) & 1 & 1 & 1 & & & & & & & & & & & & \\
\hline $\mathrm{A} 24$ & & 2 & & ugly (1) & 1 & 1 & 1 & & & & & & & & & & & & \\
\hline A1 & & & & board (0) & & & & & & & & & & & & & & & \\
\hline $\mathrm{A} 8$ & & & & sheet $(0)$ & & & & & & & & & & & & & & & \\
\hline A16 & & & & square $(0)) n$ ) & & & & & & & & & & & & & & & \\
\hline $\mathrm{A} 25$ & & & & grace $(0)(\mathrm{n})$ & & & & & & & & & & & & & & & \\
\hline A27 & & & & needle $(0)(n)$ & & & & & & & & & & & & & & & \\
\hline A28 & & & & rude $(0)$ & & & & & & & & & & & & & & & \\
\hline A30 & & & & trunk $(0)$ & & & & & & & & & & & & & & & \\
\hline A31 & & & & brow (0) & & & & & & & & & & & & & & & \\
\hline A37 & & & & advance $(0)(\mathrm{v})$ & & & & & & & & & & & & & & & \\
\hline A39 & & & & discharge (0) (v) & & & & & & & & & & & & & & & \\
\hline
\end{tabular}

Table 8. The students' results on and evaluation of the English test on polysemous words with a focus on the items for which the students were able to give all the correct senses, the table listing the test items in order of the number of correct answers starting with the item that received the highest score (polysemous word: $\mathrm{S}=$ sure that the word is known, $\mathrm{TK}=$ the word is thought to be known, $\mathrm{NK}=$ the word is not known) 


\begin{tabular}{|c|c|c|c|c|c|c|c|c|c|c|c|c|c|c|c|c|c|}
\hline \multirow{3}{*}{ NO } & \multirow{2}{*}{\multicolumn{3}{|c|}{$\begin{array}{l}\text { POLYSEMOUS } \\
\text { WORD (INFO) }\end{array}$}} & \multirow{3}{*}{$\begin{array}{c}\text { WORD } \\
\text { (NO OF CORRECT } \\
\text { ANSWERS) }\end{array}$} & \multicolumn{13}{|c|}{ MEANINGS } \\
\hline & & & & & \multicolumn{5}{|c|}{ SURE } & \multicolumn{4}{|c|}{ THINK SURE } & \multicolumn{4}{|c|}{ NOT SURE } \\
\hline & $\mathrm{S}$ & TK & NK & & 1 & 2 & 3 & 4 & 5 & 1 & 2 & 3 & \begin{tabular}{l|l}
4 & 5 \\
\end{tabular} & 1 & 2 & 3 & \begin{tabular}{|l|l|}
4 & 5 \\
\end{tabular} \\
\hline A19 & 13 & 1 & & greppa (14) & 14 & 14 & & & & & & & & & & & \\
\hline A26 & 10 & 4 & & krasch (14) & 8 & 12 & & & & 4 & 1 & & & 1 & & & \\
\hline A24 & 12 & 1 & & dragningskraft (13) & 11 & 11 & & & & 1 & 1 & & & & & & \\
\hline $\mathrm{A} 12$ & 12 & 1 & & platt (13) & 11 & 10 & & & & 1 & 2 & & & & & & \\
\hline A13 & 12 & 1 & & samsas (13) & 11 & 10 & & & & 1 & 2 & & & & & & \\
\hline A29 & 7 & 5 & $1(1)$ & huvudbry (13) & 11 & 10 & & & & 1 & 2 & & & & & & \\
\hline $\mathrm{A} 25$ & 10 & 2 & & revolutionerande (13) & 11 & 8 & 11 & & & 1 & 3 & 2 & & 1 & 2 & & \\
\hline A11 & 10 & 2 & & atmosfär (13) & 10 & 11 & & & & 2 & 1 & & & & & & \\
\hline A27 & 10 & 2 & & begrava (12) & 12 & 9 & 11 & & & & 3 & 1 & & & & & \\
\hline A31 & 8 & 2 & & frälst (10) & 7 & 8 & 9 & & & 1 & 1 & 1 & & 1 & 1 & & \\
\hline A8 & 3 & 7 & & remiss (10) & 4 & 7 & & & & 5 & 4 & & & 1 & & & \\
\hline A9 & 8 & 1 & & avbryta (9) & 8 & 8 & 6 & & & 1 & 1 & 2 & & & & 1 & \\
\hline A4 & 7 & 1 & & tagen (9) & 6 & 3 & 5 & & & 2 & 1 & 2 & & & & 2 & \\
\hline A21 & 7 & 2 & & nicka (9) & 6 & 5 & 7 & & & 2 & 3 & 2 & & 1 & 1 & & \\
\hline A22 & 6 & 2 & & gap (8) & 4 & 7 & 6 & & & 4 & 1 & 1 & & 1 & & & \\
\hline A17 & 5 & 3 & & fiktion (8) & 3 & 5 & & & & 3 & 1 & & & & & & \\
\hline A37 & 6 & 1 & & grina (7) & 6 & 6 & 5 & & & & & & & & & 1 & \\
\hline A15 & 6 & & & harmoni (6) & 4 & 6 & 6 & & & 2 & & & & & & & \\
\hline A33 & 4 & 1 & & flyktig (5) & 3 & 5 & 5 & 4 & & 1 & & & 1 & 1 & & & \\
\hline A30 & 4 & 1 & & darra (5) & 4 & 3 & 3 & 4 & & 1 & 1 & 2 & & & 1 & & 1 \\
\hline A1 & 4 & & & börja (4) & 4 & 4 & 3 & 3 & 4 & & & & 1 & & & 1 & \\
\hline A7 & 3 & 1 & & skugga (4) & 3 & 3 & 2 & 4 & & & 1 & 2 & & 2 & & & \\
\hline A38 & 1 & 1 & $2(2)$ & teknikalitet (4) & 1 & 1 & & & & 1 & 1 & & & 1 & 1 & & \\
\hline $\mathrm{A} 2$ & 3 & & & ersättning (3) & 3 & 2 & 1 & 1 & & & & 1 & 2 & & 1 & 1 & \\
\hline A32 & 3 & & & fullfjädrad (3) & 1 & 3 & 3 & & & & & & & 2 & & & \\
\hline A35 & 2 & & & herravälde (2) & 2 & 2 & 2 & 2 & & & & & & & & & \\
\hline A20 & 1 & & & brunn (1) & 1 & 1 & 1 & 1 & & & & & & & & & \\
\hline A28 & 1 & & & dirigera (1) & 1 & 1 & 1 & 1 & & & & & & & & & \\
\hline A34 & 1 & & & avig (1) & 1 & 1 & 1 & 1 & & & & & & & & & \\
\hline A39 & 1 & & & krafsa (1) & 1 & 1 & 1 & & & & & & & & & & \\
\hline A6 & 1 & & & marginal (1) & 1 & 1 & & & & & & & & & & 1 & \\
\hline A36 & & 1 & & arbetsam (1) & & & & & & 1 & 1 & & & & & & \\
\hline A3 & & & & tillfälle $(0)$ & & & & & & & & & & & & & \\
\hline A5 & & & & dryg (0) & & & & & & & & & & & & & \\
\hline A10 & & & & element $(0)$ & & & & & & & & & & & & & \\
\hline A14 & & & & depression $(0)$ & & & & & & & & & & & & & \\
\hline A16 & & & & jäsa (0) & & & & & & & & & & & & & \\
\hline A18 & & & & lukta (0) & & & & & & & & & & & & & \\
\hline A23 & & & & koloni $(0)$ & & & & & & & & & & & & & \\
\hline A40 & & & & tetig $(0)$ & & & & & & & & & & & & & \\
\hline
\end{tabular}

Table 9. The students' results on and evaluation of the Swedish test on polysemous words with a focus on the items for which the students were able to give all the correct senses, the table listing the test items in order of the number of correct answers starting with the item that received the highest score (polysemous

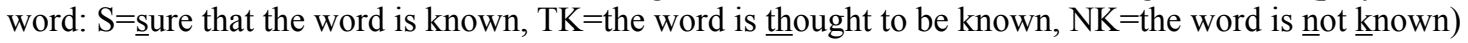

Tables 10 (English items) and 11 (Swedish items) present the results for words for which subjects were unable to offer all the correct senses and/or indicated meanings that were incorrect. Here the word with the fewest number of incorrect answers comes first. These two tables should be deciphered in the same way as Tables 8 and 9 discussed above. There are only three additions. First, there is one column indicating the total number of incorrect senses offered by the students for a particular word. For the word idle (test item A32), for instance, a total of 14 incorrect meanings were indicated. Secondly, there is one column showing the distribution of correct meanings given by the informants (directly after the column with the number of errors for each word). For the 
English test item nail (A35), for example, the student who made the mistake got both meanings right but also indicated one incorrect meaning. Thirdly, if the most frequent sense tallies with the word's core sense (as presented in The New Oxford Dictionary of English (1998)), an asterisk has been used to indicate this correlation (under MEANINGS (first), column 1). (No dictionary indicating the core senses for the Swedish words could be found.)

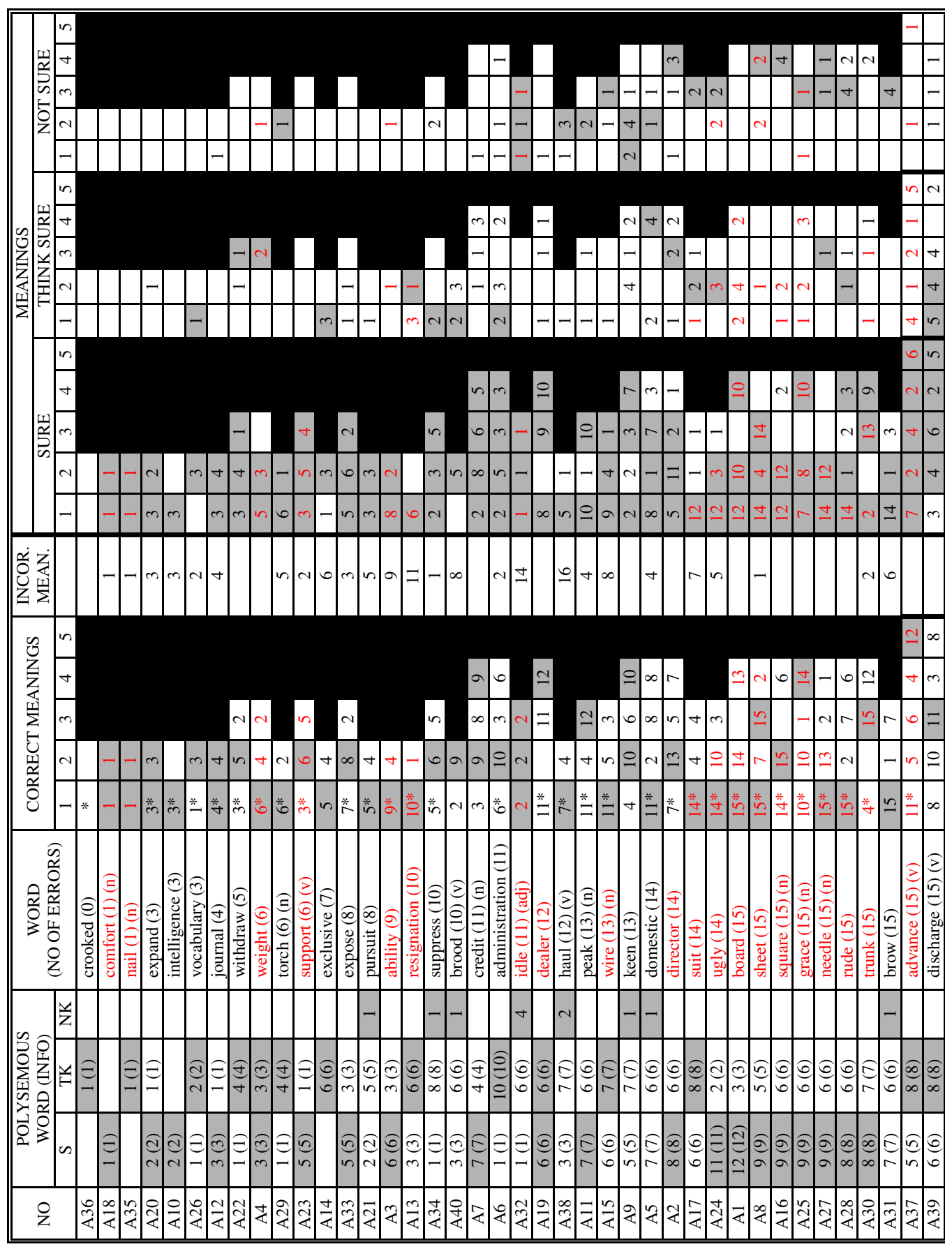

Table 10. The students' results on and evaluation of the English test on polysemous words with a focus on the items for which the informants were unable to give all the correct senses (polysemous word: $S=\underline{\text { sure }}$ that the word is known, $\mathrm{TK}=$ the word is thought to be known, $\mathrm{NK}=$ the word is not known) 


\begin{tabular}{|c|c|c|c|c|c|c|c|c|c|c|c|c|c|c|c|c|c|c|c|c|c|c|c|}
\hline \multirow{3}{*}{ NO } & \multirow{2}{*}{\multicolumn{3}{|c|}{$\begin{array}{l}\text { POLYSEMOUS } \\
\text { WORD (INFO) }\end{array}$}} & \multirow{3}{*}{$\begin{array}{c}\text { WORD } \\
\text { (NO OF ERRORS) }\end{array}$} & \multirow{2}{*}{\multicolumn{4}{|c|}{ CORRECT MEANINGS }} & INCOR. & \multicolumn{14}{|c|}{ MEANINGS } \\
\hline & & & & & & & & & MEAN. & \multicolumn{5}{|c|}{ SURE } & \multicolumn{5}{|c|}{ THINK SURE } & \multicolumn{4}{|c|}{ NOT SURE } \\
\hline & $\mathrm{S}$ & TK & NK & & 1 & 2 & 3 & 4 & & 1 & 2 & 3 & 4 & 5 & 1 & 2 & 3 & 4 & 5 & \begin{tabular}{|l|}
1 \\
\end{tabular} & 2 & & \\
\hline $\mathrm{A} 19$ & $1(1)$ & & & greppa (1) & 1 & 1 & & & 1 & & & & & & & & & & & & & & \\
\hline A26 & $1(1)$ & & & krasch (1) & & 1 & & & & & 1 & & & & & & & & & & & & \\
\hline A24 & $2(2)$ & & & dragningskraft (2) & 2 & 2 & & & 2 & 2 & 2 & & & & & & & & & & & & \\
\hline A12 & $2(2)$ & & & platt (2) & 1 & 2 & & & 1 & 1 & 1 & & & & & 1 & & & & & & & \\
\hline A13 & $2(2)$ & & & samsas (2) & 2 & 1 & & & 1 & 2 & & & & & & 1 & & & & & & & \\
\hline $\mathrm{A} 29$ & $2(2)$ & & & huvudbry (2) & 2 & 2 & & & 3 & 2 & 1 & & & & & & & & & & 1 & & \\
\hline A25 & $1(1)$ & $1(1)$ & & revolutionerande (2) & 1 & 1 & 2 & & & 1 & & 1 & & & & & & & & & & & \\
\hline A11 & $1(1)$ & $1(1)$ & & atmosfär (2) & 1 & 2 & & & 1 & 1 & 2 & & & & & & & & & & & & \\
\hline A27 & $2(2)$ & $1(1)$ & & begrava (3) & 3 & 1 & 2 & & & 2 & 1 & 1 & & & & & & & & & & & \\
\hline $\mathrm{A} 31$ & $2(2)$ & $2(2)$ & 1 & frälst (5) & 5 & 4 & & & 1 & 3 & 3 & & & & 1 & 1 & & & & & & & \\
\hline A8 & $2(2)$ & $3(3)$ & & remiss (5) & 2 & 5 & & & 5 & 1 & 3 & & & & & & & & & \begin{tabular}{|l|l|l}
1 & & $r$
\end{tabular} & 1 & & \\
\hline A9 & $4(4)$ & $2(2)$ & & avbryta (6) & 5 & 6 & 1 & & 3 & 4 & 4 & 1 & & & & 1 & & & & & & & \\
\hline $\mathrm{A} 4$ & $5(5)$ & $1(1)$ & & tagen (6) & 3 & 5 & 4 & & & 2 & 5 & 3 & & & 1 & & 1 & & & & & & \\
\hline $\mathrm{A} 21$ & $4(4)$ & $2(2)$ & & nicka (6) & 5 & 2 & 5 & & 1 & 2 & 2 & 3 & & & 2 & & 1 & & & & & & \\
\hline $\mathrm{A} 22$ & $5(5)$ & $2(2)$ & & gap (7) & 4 & 6 & 6 & & 5 & 4 & 5 & 5 & & & & & & & & & & & \\
\hline A17 & $3(3)$ & $4(4)$ & & fiktion (7) & 6 & 5 & & & 8 & 4 & 3 & & & & & 1 & & & & \begin{tabular}{|l|}
1 \\
\end{tabular} & 1 & & \\
\hline A37 & $5(5)$ & $3(3)$ & & grina (8) & 8 & 2 & 6 & & & 6 & 1 & 3 & & & 1 & 1 & 1 & & & & & 2 & \\
\hline A15 & $6(6)$ & $3(3)$ & & harmoni (9) & 3 & 6 & 9 & & 3 & 2 & 2 & 7 & & & 1 & 3 & 1 & & & & & & \\
\hline A33 & $5(5)$ & $5(5)$ & & flyktig (10) & 5 & 7 & 4 & 7 & 2 & 5 & 3 & 2 & 4 & & & 2 & 1 & 2 & & & 1 & 1 & \\
\hline $\mathrm{A} 30$ & $8(8)$ & $2(2)$ & & darra (10) & 9 & 4 & 2 & 8 & 2 & 8 & 3 & 1 & 6 & & & & 1 & 1 & & & & & \\
\hline A1 & $10(10)$ & & & börja (11) & 11 & 11 & 4 & 2 & 1 & 11 & 11 & 3 & & 7 & & 1 & & 2 & 2 & & & 1 & \\
\hline A7 & $10(10)$ & $1(1)$ & & skugga (11) & 5 & 8 & 9 & 9 & 1 & 4 & 7 & 8 & 5 & & & 1 & & 2 & & & & & \\
\hline A38 & $4(4)$ & $5(5)$ & 2 & teknikalitet (11) & 6 & 8 & & & 11 & 4 & 4 & & & & 1 & 2 & & & & \begin{tabular}{|l|}
1 \\
\end{tabular} & 2 & & \\
\hline $\mathrm{A} 2$ & $10(10)$ & $1(1)$ & & ersättning (12) & 12 & 10 & 5 & 4 & 1 & 11 & 9 & 4 & 3 & & & 1 & & 1 & & & & 1 & \\
\hline A32 & $6(6)$ & $5(5)$ & 1 & fullfjädrad (12) & 2 & 12 & 11 & & 2 & 1 & 8 & 8 & & & & 2 & 2 & & & & \begin{tabular}{|l|l|}
1 \\
\end{tabular} & \begin{tabular}{|l|}
1 \\
\end{tabular} & \\
\hline A35 & $3(3)$ & $10(10)$ & & herravälde (13) & 12 & 8 & 12 & 4 & 3 & 7 & 4 & 6 & 2 & & 2 & 3 & 4 & & & & & & \\
\hline $\mathrm{A} 20$ & $11(11)$ & $3(3)$ & & brunn (14) & \begin{tabular}{|l|}
14 \\
\end{tabular} & 2 & 6 & 5 & & 13 & 2 & 1 & 2 & & & & 3 & 1 & & & & \begin{tabular}{|l|}
1 \\
\end{tabular} & 2 \\
\hline $\mathrm{A} 28$ & $12(12)$ & $2(2)$ & & dirigera (14) & 14 & 13 & 13 & & & 9 & 11 & 11 & & & 2 & 2 & 1 & & & \begin{tabular}{|l|}
2 \\
\end{tabular} & & & \\
\hline A34 & $7(7)$ & $5(5)$ & 1 & avig (14) & 12 & 9 & 6 & 6 & 1 & 9 & 5 & 1 & 3 & & & 3 & 3 & 3 & & 2 & & 1 & \\
\hline A39 & $8(8)$ & $5(5)$ & & krafsa (14) & 14 & 7 & 9 & & 13 & 11 & 6 & 6 & & & 2 & 1 & 2 & & & & & 11 & \\
\hline A6 & $8(8)$ & $5(5)$ & 1 & marginal (14) & 13 & 12 & 3 & & 3 & 9 & 6 & 1 & & & 2 & 4 & 1 & & & \begin{tabular}{|l|}
1 \\
\end{tabular} & 1 & 1 & \\
\hline A36 & $10(10)$ & $4(4)$ & & arbetsam (14) & 14 & 3 & & & 15 & 10 & 2 & & & & 2 & 1 & & & & & & & \\
\hline $\mathrm{A} 3$ & $14(14)$ & $1(1)$ & & tillfälle (15) & 11 & 14 & 3 & 14 & 5 & 9 & 14 & 2 & 12 & & 2 & & & 1 & & & & 1 & \\
\hline A5 & $13(13)$ & $1(1)$ & & dryg (15) & 9 & 14 & 5 & 11 & 2 & 6 & 11 & 2 & 4 & & 2 & 1 & 2 & 5 & & \begin{tabular}{|l|}
1 \\
\end{tabular} & & & 1 \\
\hline $\mathrm{A} 10$ & $10(10)$ & $3(3)$ & & element (15) & \begin{tabular}{|l|}
11 \\
\end{tabular} & 5 & 15 & 10 & & 7 & 4 & 13 & 7 & 1 & 3 & & 1 & 3 & 1 & & 1 & & \\
\hline A14 & $11(11)$ & $3(3)$ & & depression (15) & 15 & 14 & 1 & 3 & 2 & 13 & 11 & & 1 & & 1 & 2 & 1 & 1 & & & & & 1 \\
\hline A16 & $11(11)$ & $3(3)$ & 1 & jäsa (15) & 13 & 7 & & & 16 & 10 & 6 & & & 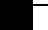 & 1 & 1 & & & & \begin{tabular}{|l|}
1 \\
\end{tabular} & & & \\
\hline A18 & $13(13)$ & $2(2)$ & & lukta (15) & 9 & 10 & 12 & 6 & & 8 & 6 & 8 & 3 & & & 2 & & 2 & & & 1 & 2 & \begin{tabular}{|l|l|}
1 & 2 \\
\end{tabular} \\
\hline A23 & $7(7)$ & $8(8)$ & & koloni (15) & 11 & 13 & 1 & 8 & & 7 & 5 & & 7 & & 3 & 6 & & 1 & & & & & \\
\hline $\mathrm{A} 40$ & $3(3)$ & $7(7)$ & 4 & tetig (15) & 12 & 2 & & & 13 & 9 & 2 & & & & 2 & & & & & & & & \\
\hline
\end{tabular}

Table 11. The students' results on and evaluation of the Swedish test on polysemous words with a focus on the items for which the informants were unable to give all the correct senses (polysemous word: $\mathrm{S}=\underline{\text { sure }}$ that the word is known, $\mathrm{TK}=$ the word is thought to be known, $\mathrm{NK}=$ the word is not known)

As discussed in connection with Tables 8 and 9, the informants showed, somewhat surprisingly, great confidence in their mastery of words for which they knew all the correct senses and had indicated none of the incorrect senses. What is even more surprising is, as already hinted at in connection with Table 7 (the students' self-evaluation), that the subjects also displayed great confidence with items for which they did not receive a point (either by not indicating all the correct senses or by indicating incorrect ones). In fact, in only 8 out of 40 cases (column NK under POLYSEMOUS WORD (INFO)) did most of the students write that they did not know the polysemous word (see Table 10), a vast majority indicating that they were either sure of the item or thought that they knew the item. This is especially surprising with the words board, sheet, square, grace, needle, rude and trunk for which no student actually received a point. (As mentioned before, these were all words for which four senses were sought.) Since not many incorrect meanings were given for these words, it may be that the students here played it safe and only indicated those senses they were certain of or that they simply did not think that the words had that many meanings. The degree of certainty in their evaluation points to the latter, emphasising the students' lack of vocabulary depth. As before, this is not only limited to their L2. Although less pronounced, the same thing can be seen in their L1 (Table 11) where again a vast majority of the subjects wrote that they were sure of words for which none of them could give all the meanings sought.

It is also interesting to consider the incorrect senses indicated by the informants. As in Odefalk's investigation, many of these were synforms. For example, quite a few of the participants thought that beundrande (idolising (from idol)) was one of the meanings of the polysemous word idle (test item A32). Similarly, even more students believed that yla (howl) was one of the correct 
senses of haul (test item A38), probably visualising the orthographic form of the word howl without being sure of its exact pronunciation. Another common group of incorrect meanings offered were those that remind phonologically and/or orthographically of the word tested. This appeared to be the case especially if the beginning looked the same, as exemplified by the word bredda (broaden) which a great many of the learners thought was one of the meanings of the word brood (test item A40). The bathtub effect, according to which the first part of a word is most salient and thus remembered the best, appears to be at work here (Aitchison 2003). In general, it seems that the subjects in the present study based many of their incorrect answers on phonological similarities. This, as discussed in Subsection 2.1, is normally an indication of a low-proficiency level. Since acquiring senses of polysemous words is equal to developing vocabulary depth, which is more difficult than developing vocabulary width, it may be that the students, not having created enough links, were subconsciously prompted to resort to the more basic approach of phonological similarity.

Finally, Table 12 presents the students' results in relation to meaning $\left(1^{\text {st }}, 2^{\text {nd }}, 3^{\text {rd }}, 4^{\text {th }}\right.$ or $\left.5^{\text {th }}\right)$ for words for which they were not able to give all the correct senses and/or gave incorrect senses. As stated in Schmitt (2010) and confirmed by Odefalk (2004), the informants in the present study too appear to have a better knowledge of the most frequent sense of a polysemous word than the less frequent ones. The only anomalies in Table 12 are the results on the fourth and fifth senses with the English items where there is an increase in correctness. However, it must be assumed that the main reason for this is that the number of possible correct meanings is here relatively low (210 for the fourth sense and only 30 for the fifth sense) and can therefore not really be comparable to the number of first (402 possible senses), second (again 402) and third (325) meanings. The results on the fourth and fifth senses on the Swedish test must of course therefore also be ascribed to mere chance.

Furthermore, in Subsection 2.2 it was shown that offering the core meaning of a polysemous word may help students comprehend and retain other meanings of the same word. In order to find out if core meanings had a similar positive effect on the students' mastery in the present investigation, a comparison between the most frequent meaning tested and the core sense was made. It was believed that if there was a concentration of correlations between the core sense and the most frequent meaning for the words for which most students had offered correct answers, the core sense could be shown to have had a positive impact on the students' results. However, when The New Oxford Dictionary of English was consulted, it turned out that there was a correlation in a vast majority of cases, thus rendering it impossible to draw any conclusions in this respect. The very fact that a majority of the most frequent meanings also were the core senses may of course have contributed to the result that the students did the best on the most common meanings.

\begin{tabular}{|l|c|c|c|c|c|}
\hline \multirow{2}{*}{ STUDENTS } & \multicolumn{5}{|c|}{ POLYSEMOUS WORD } \\
\cline { 2 - 6 } & 1st meaning & 2nd meaning & 3rd meaning & 4th meaning & 5th meaning \\
\hline Swedish students & $\begin{array}{c}73.9 \% \\
\text { English test }\end{array}$ & $\begin{array}{c}53.5 \% \\
(=297 / 402)\end{array}$ & $\begin{array}{c}44.6 \% \\
(=215 / 402)\end{array}$ & $\begin{array}{c}53.8 \% \\
(=145 / 325)\end{array}$ & $\begin{array}{c}66.7 \% \\
(=113 / 210)\end{array}$ \\
\hline $\begin{array}{l}\text { Swedish students } \\
\text { Swedish test }\end{array}$ & $\begin{array}{c}77.8 \% \\
(=288 / 370)\end{array}$ & $\begin{array}{c}66.8 \% \\
(=247 / 370)\end{array}$ & $\begin{array}{c}51.0 \% \\
(=156 / 306)\end{array}$ & $\begin{array}{c}48.7 \% \\
(=97 / 199)\end{array}$ & $\begin{array}{c}34.1 \% \\
(=14 / 41)\end{array}$ \\
\hline
\end{tabular}

Table 12. The total number of correct answers in relation to meaning - Swedish students

The corresponding results for the native speaker of English, shown in Table 13, indicate less sensitivity to frequency. However, research on larger groups of natives must be performed before any real conclusions can be drawn in this respect. 


\begin{tabular}{|c|c|c|c|c|c|}
\hline STUDENT & \multicolumn{5}{|c|}{ POLYSEMOUS WORD } \\
\hline \multirow{2}{*}{$\begin{array}{c}\text { Native speaker } \\
\text { of English }\end{array}$} & $1^{\text {st }}$ meaning & $2^{\text {nd }}$ meaning & $3^{\text {rd }}$ meaning & $4^{\text {th }}$ meaning & $5^{\text {th }}$ meaning \\
\cline { 2 - 6 } & $\begin{array}{c}66.7 \% \\
(=12 / 18)\end{array}$ & $\begin{array}{c}72.2 \% \\
(=13 / 18)\end{array}$ & $\begin{array}{c}73.3 \% \\
(=11 / 15)\end{array}$ & $\begin{array}{c}60.0 \% \\
(=6 / 10)\end{array}$ & $\begin{array}{c}100.0 \% \\
(=1 / 1)\end{array}$ \\
\hline
\end{tabular}

Table 13. The total number of correct answers in relation to meaning - native speaker

\subsection{Individual L1 and L2 knowledge of polysemous words}

Tables 14 and 15 below show the students' individual scores on the English and Swedish tests respectively. For a majority of the 15 students, there is a clear correlation between what they achieved in their L2 and their performance in their mother tongue. Whereas five learners - Students $2,5,7,8$ and 11 (indicated in orange) - received results above the mean in both languages, seven learners - Students 1, 4, 6, 9, 12, 13 and 15 (highlighted in yellow) - received results below the mean on both tests. It is thus clearly shown that if you are a high- or low-achiever in your first language, this is mirrored in your L2 results to a large extent.

\begin{tabular}{|c|c|}
\hline STUDENT & $\begin{array}{c}\text { SCORE FOR } \\
\text { POLYSEMOUS WORDS } \\
\text { ENGLISH TEST } \\
\text { (40 ITEMS) } \\
\text { (MEAN: } 13.2 \text { ) }\end{array}$ \\
\hline STUDENT 3 & 22 \\
\hline STUDENT 11 & 20 \\
\hline STUDENT 5 & 18 \\
\hline STUDENT 2 & \multirow{3}{*}{14} \\
\hline STUDENT 7 & \\
\hline STUDENT 8 & \\
\hline STUDENT 9 & \multirow{3}{*}{13} \\
\hline STUDENT 14 & \\
\hline $\begin{array}{l}\text { STUDENT } 15 \\
\end{array}$ & \\
\hline STUDENT 1 & \multirow[t]{2}{*}{11} \\
\hline STUDENT 12 & \\
\hline STUDENT 4 & \multirow{3}{*}{9} \\
\hline STUDENT 6 & \\
\hline STUDENT 13 & \\
\hline $\begin{array}{l}\text { STUDENT } 10 \\
\end{array}$ & 8 \\
\hline
\end{tabular}

Table 14. The students' individual scores on polysemous words (English test)

\begin{tabular}{|c|c|}
\hline STUDENT & $\begin{array}{c}\text { SCORE FOR } \\
\text { POLYSEMOUS WORDS } \\
\text { SWEDISH TEST } \\
\text { (40 ITEMS) } \\
\text { (MEAN: } 15.3 \text { ) }\end{array}$ \\
\hline STUDENT 11 & 23 \\
\hline STUDENT 14 & \multirow[t]{2}{*}{19} \\
\hline STUDENT 5 & \\
\hline STUDENT 10 & 18 \\
\hline STUDENT 7 & \multirow[t]{2}{*}{17} \\
\hline STUDENT 8 & \\
\hline STUDENT 2 & 16 \\
\hline STUDENT 3 & \multirow[t]{2}{*}{15} \\
\hline STUDENT 12 & \\
\hline STUDENT 9 & \multirow[t]{2}{*}{14} \\
\hline STUDENT 15 & \\
\hline STUDENT 1 & \multirow[t]{2}{*}{13} \\
\hline STUDENT 13 & \\
\hline STUDENT 6 & 9 \\
\hline STUDENT 4 & 8 \\
\hline
\end{tabular}

Table 15. The students' individual scores on polysemous words (Swedish test)

\section{Pedagogical implications of the results}

As discussed in Subsection 2.1, creating links between words is a difficult and time-consuming task. This is substantiated further by the fact that even advanced students such as a majority of the ones included in the present investigation display poor knowledge of different senses of polysemous words in their L2 as well as in their L1. In order to promote network building, teachers therefore need to make use of all the pedagogical tools available. For words with multiple meanings, the most useful tool appears to be frequency, i.e. when selecting items for the teaching syllabus frequency definitely needs to be taken into account. However, the present study shows that while the frequency of the polysemous word itself had little or no relevance as to whether the meanings of the word were known or not (see Figures 3 and 4), the relative frequencies of the senses themselves played a great role, the most frequent meaning tested being by far the best known (see Table 12). Starting with the most frequent senses may therefore be a good point of

3 Item A27 (needle) is here excluded because it differed in the meanings sought for between the native speaker and the Swedish informants. (See also Footnote 2.) 
departure when teaching meanings of polysemous words to L2 learners. Furthermore, although it could not be either substantiated or refuted in the present study since the core sense in a majority of cases also was the most frequent sense tested, other research has shown that explaining the core sense of a polysemous word may help learners comprehend and retain other, more peripheral meanings of the same word to a greater extent. (As pointed out previously, however, the very fact that a majority of the most frequent meanings tested coincided with their words' core senses may have helped increase the students' mastery of the most common meanings.) This may therefore also be a fruitful stepping board when approaching polysemous words from an L2 perspective. The New Oxford Dictionary of English (1998), which to the present author's knowledge is the only dictionary which lists the core sense first, may here be of great help to language teachers of English.

Finally, since there appears to be a correlation between students' knowledge of polysemous words in their L1 and their mastery of these types of items in their L2, learners may benefit from being made aware of this language phenomenon early in their L1. Thus cooperation between L1 and L2 instructors seems important.

\section{References}

Aitchison, J. 2003 ( $3^{\text {rd }}$ ed.): Words in the mind. An introduction to the mental lexicon. Oxford: Blackwell.

Alm-Arvius, C. 1998: Introduction to semantics. Lund: Lund University Press.

Alm-Arvius, C. 2003: Figures of speech. Lund: Studentlitteratur.

Anderson, J. R. 1983: The architecture of cognition. Cambridge, MA: Harvard University Press.

Albrechtsen, D./Haastrup, K./Henriksen, B. 2008: Vocabulary and writing in a first and second language: Processes and development. New York: Palgrave Macmillan.

Anderson, J. R. 1990: Cognitive psychology and its implications. (3 ${ }^{\text {rd }}$ ed.) New York: Erlbaum.

Bachman, L. F./Davidson, F. G./Ryan, K./Choi, I. C. 1995: An investigation into the comparability of two tests of English as a foreign language: The Cambridge TOEFL comparability study. Cambridge: UCLES.

Bensoussan, M./Laufer, B. 1984: 'Lexical guessing in context in EFL reading comprehension.' In Journal of Research in Reading 7, 15-32.

Carnine, D./Kameeniu, E. J./Coyle, G. 1984: 'Utilization of contextual information in determining the meaning of unfamiliar words.' In Reading Research Quarterly 19,188-204.

Carroll, J. B. 1983: 'Psychometric theory and language testing.' In Oller, J. W. (ed.), Issues in language testing research. Rowley, MA: Newbury House.

Chihara, T./Oller, J./Weaver, K./Chavez-Oller, M. A. 1977: ‘Are cloze items sensitive to discourse constraints?' In Language Learning 27, 63-73.

Cohen, A. D./Aphek, E. 1981: 'Easifying second language learning.' In Studies in Second Language Acquisition 3 (2), 221-236.

Crossley, S./Salsbury, T./McNamara, D. 2010: 'The development of polysemy and frequency use in English second language speakers.' In Language Learning 60, 3, 573-605.

De Angelis, G. 2007: Third or additional language acquisition. Buffalo: Multilingual Matters.

Foss, D. 1970: 'Some effects of ambiguity upon sentence comprehension.' In Journal of Verbal Learning and Verbal Behavior 9, 699-706.

Greidanus, T./Beks, B./Wakely, R. 2005: 'Testing the development of French word knowledge by advanced Dutch- and English-speaking learners and native speakers.' In The Modern Language Journal 89(2), 221-238.

Greidanus, T./Bogaards, P./Van Der Linden E./Nienhuis, L./De Wolf, T. 2004: 'The construction and validation of a deep word knowledge test for advanced learners of French.' In Bogaards, P./Laufer, B., Vocabulary in a second language. Amsterdam: John Benjamins.

Gyori, G. 2002: 'Semantic change and cognition.' In Cognitive Linguistics 13 (2), 123-166.

Hargevik, S. 1998: Hargeviks 5000 ord. Göteborg: Utbildningsstaden AB.

Hulstijn, J. H. 2000: 'Intentional and incidental second-language vocabulary learning: A reappraisal of elaboration, rehearsal and automaticity.' In Robinson, P. (ed.), Cognition and second language instruction. Cambridge: Cambridge University Press.

Jenkins, J. R./Dixon, R. 1983: ‘Vocabulary learning.' In Contemporary Educational Psychology 8, 237-260. 
Lackner, J. R./Garrett, M. F. 1972: 'Resolving ambiguity: Effects of biasing context in the unattended ear.' In Cognition $1,359-372$.

Lakoff, G. 1987: Women, fire, and dangerous things: What categories reveal about the mind. Chicago: Chicago University Press.

Langacker, R. W. 2002 Concept, image, and symbol: The cognitive basis of grammar. New York: Mouton de Gruyter.

Leys, M./Fielding, L./Herman, P./Pearson, P. D. 1983: 'Does cloze measure intersentence comprehension? A modified replication of Shanahan, Kamil, and Tobin.' In Niles, J. A./Harris, L. A. (eds.), Searches for meaning in reading/ Language processing and instruction. $32^{\text {nd }}$ Yearbook of National Reading Conference. New York: Rochester.

Longman dictionary of contemporary English 1987. Harlow: Longman.

Lowie, W. M./Verspoor, M. H. 2001: 'Het leren van polyseme woorden vanuit de kernbetekenis.' Toegepaste Taalwetenschap in Artikelen 65 (1), 9-21.

Mackay, D. 1966: 'To end ambiguous sentences.' In Perception and Psychophysics 1, 426-436.

Meara, P. 1978: 'Learners' word associations in French.' In Interlanguage Studies Bulletin Utrecht 3,192-211.

Murphy, M. L. 2003: Semantic relations and the lexicon: antonymy, synonymy and other paradigm. Cambridge: Cambridge University Press.

Murphy, G. L. 2004: The big book of concepts. Cambridge, MA: MIT Press.

Namei, S. 2002: 'The bilingual lexicon from a developmental perspective: A word association study of Persian-Swedish bilinguals.' Centre for Research on Bilingualism: Stockholm University.

Namei, S. 2004: 'Bilingual lexical development: A Persian-Swedish word association study.' In International Journal of Applied Linguistics 14(3), 363-388.

Nation, P. 1990: Teaching and learning vocabulary. New York: Newbury House.

Nation, P. 2000: Learning vocabulary in a second language. Cambridge: Cambridge University Press.

Nation, P. 2001: Learning Vocabulary in another Language. Cambridge: Cambridge University Press.

Nation, P. 2008: Teaching vocabulary: Strategies and techniques. Boston, MA: Heinle.

The New Oxford Dictionary of English 1998. Oxford: Clarendon.

Norstedts engelska ordbok: Engelsk-svensk/svensk-engelsk. (CD-Rom version)

Norstedts stora engelsk-svenska ordbok 1993. Stockholm: Nordstedts Förlag AB.

Nunberg, G. 1979: The non-uniqueness of semantic solutions: Polysemy. Linguistics and philosophy 3:143-184.

Odefalk, A. 2004: 'A study of Swedish students' mastery of words and their meaning(s).'Halmstad University: Unpublished undergraduate study.

Oller, J. W. 1979: Language tests at school. London: Longman.

Piper, T. H./Leicester, P. F. 1980: 'Word association behavior as an indicator of English language proficiency.' Educational Resources Information Center (ERIC) documents ED227651.

Pustejovski, J. 1995: The generative lexicon. Cambridge, MA: MIT Press.

Read, J. 1993: 'The development of a new measure of L2 vocabulary knowledge.' In Language Testing 10, 355-371.

Rijpma, M. T. 1999: The effectiveness of the learning strategy of core meaning on guessing and retention of second language polysemous words. University of Groningen: Unpublished master's thesis.

Rye, J. 1985: 'Are cloze items sensitive to constraints across sentences? A Review.' In Journal of Research in Reading (UKRA) 8, 94-105.

Schmitt, N. 1998: 'Tracking the incremental acquisition of second language vocabulary: A longitudinal study.' In Language Learning 48, 2, 281-317.

Schmitt, N. 2010: Reseaching vocabulary: A vocabulary research manual. New York: Palgrave MacMillan.

Singleton, D. 1999: Exploring the second language mental lexicon. Cambridge: Cambridge University Press.

Sternberg, R. J. 1987: 'Most vocabulary is learned from context.' In McKeown, M. G./Curtis, M. E. (eds.), The nature of vocabulary acquisition. Erlbaum: Hillsdale, NJ.

Strömberg, A. 1979: Stora synonymordboken. Stockholm: Strömberg.

Strömberg, A. 1998: Stora synonymordboken. Stockholm: Strömberg.

Swinney, D. 1979: 'Lexical access during sentence comprehension: (Re)consideration of context effects.' In Journal of Verbal Learning and Verbal Behavior 18, 645-659.

Söderman, T. 1993: 'Word associations of foreign language learners and native speakers:The phenomenon of a shift in response type and its relevance for lexical development.' In Ringbom, H., Near native proficiency in English. Åbo: Åbo Akademi. 
Thornbury, S. 2002: How to teach vocabulary. Harlow: Longman.

Verspoor, M. H. 1997: 'True blue: A cognitive linguistic approach to vocabulary acquisition.' In Smieja, B./Tasch, M. (eds.), Human contact through language and linguistics. Frankfurt am Main: Lang.

Verspoor, M. H. \& Lowie, W. 2003: 'Making sense of polysemous words.' In Language Learning 53, 3, 547-586.

West, M. 1953: A general service list of English words. London: Longman.

Wilks, C./Meara, P. 2002: 'Untangling word webs: Graph theory and the notion of density in second language word association networks.' In Second Language Research 18, 303-324.

Wolter, B. 2001: 'Comparing the L1 and L2 mental lexicon: A depth of individual word knowledge model'. In Studies in Second Language Acquisition 23, 41-69.

Xue, G./Nation, P. 1984: 'A university word list.' In Language Learning and Communication 3, 215-229.

Yule, G. 1996: The study of language. Cambridge: Cambridge University Press.

Zipf, G. K. 1945: 'The meaning-frequency relationship of words.' In Journal of General Psychology 33, 251-256.

http://www.svenskaakademien.se/svenska_spraket/svenska_akademiens_ordlista/saol_pa_natet/ordlista [online]. 


\section{Appendix}

The correct meanings of the English polysemous words and their translation into English.

\begin{tabular}{|c|c|c|}
\hline NO & WORD & MEANINGS \\
\hline \multirow{2}{*}{ A36 } & \multirow{2}{*}{ crooked (15) } & 1) krokig (=not straight, twisted) \\
\hline & & 2) ohederlig (=tending to cheat or deceive) \\
\hline \multirow{2}{*}{ A18 } & \multirow{2}{*}{ comfort (14) } & 1) tröst (=strength, hope, or sympathy for an unhappy person) \\
\hline & & 2) bekvämligheter (=something that satisfies one's physical needs) \\
\hline \multirow[b]{2}{*}{ A35 } & \multirow[b]{2}{*}{ nail (14) } & 1) nagel (=on your finger or toe) \\
\hline & & $\begin{array}{l}\text { 2) spik (=a thin pointed piece of metal for hammering into a piece of wood, usually to fasten the wood to } \\
\text { something else) }\end{array}$ \\
\hline \multirow{2}{*}{$\mathrm{A} 20$} & \multirow{2}{*}{ expand (12) } & 1) vidga (=to increase in size, number, volume, degree, etc.) \\
\hline & & 2) utveckla (=to make (a story, argument, etc.) more detailed by addition; enlarge on) \\
\hline \multirow{2}{*}{ A10 } & \multirow{2}{*}{ intelligence (12) } & 1) intelligens (=(good) ability to learn, reason, and understand) \\
\hline & & 2) underrättelse (=information, especially about an enemy country) \\
\hline \multirow{2}{*}{ A26 } & \multirow{2}{*}{ vocabulary (12) } & 1) ordlista (=a list of words, usually in an alphabetical order and with explanations of their meanings) \\
\hline & & 2) ordförråd (=words known, learnt, used, etc.) \\
\hline \multirow{2}{*}{ A12 } & \multirow{2}{*}{ journal (11) } & 1) tidskrift (=a serious magazine, usually produced by a specialist society) \\
\hline & & 2) dagbok (=a usually daily record of events) \\
\hline \multirow{3}{*}{ A22 } & \multirow{3}{*}{ withdraw (10) } & 1) ta tillbaka (=to take back) \\
\hline & & 2) dra tillbaka (=to take away or take back) \\
\hline & & 3) ta ut pengar (=to take out money) \\
\hline \multirow{3}{*}{ A4 } & \multirow{3}{*}{ weight (9) } & 1) vikt (=the heaviness of something) \\
\hline & & 2) börda (=(something that causes) a feeling of worry or anxiety) \\
\hline & & 3) brevpress (=a piece of heavy material used to put on different type of paper to make it lie still) \\
\hline \multirow{2}{*}{ A29 } & \multirow{2}{*}{ torch (9) } & 1) fackla (=a mass of burningmaterial tied to a stick and carried by hand to give light) \\
\hline & & 2) ficklampa (=a small electric light carried in the hand; flashlight) \\
\hline \multirow{3}{*}{ A23 } & \multirow{3}{*}{ support (9) } & 1) stötta (=to bear the weight of, especially so as to keep in place or prevent from falling) \\
\hline & & 2) stödja (=to show the truth or correctness of; substantiate) \\
\hline & & 3) försörja (=to provide especially for (a person) to live on) \\
\hline \multirow{2}{*}{ A14 } & & 1) förnäm (=that leaves out people considered to be socially unsuitable) \\
\hline & exclusive (8) & 2) exklusive (=not taking into account; without) \\
\hline & & 1) utsätta (=leave without protection) \\
\hline A33 & expose (7) & 2) avslöja (=to make known (a secretly guilty person or action)) \\
\hline & & 3) exponera (filmrulle) (=to uncover (a film) to the light, when taking a photograph) \\
\hline & & 1) förföljande (=the act of following) \\
\hline A21 & pursuit (7) & 2) utövande (=an activity to which one gives one's time, whether as work or for pleasure) \\
\hline A3 & & 1) förmåga (=having the power to do something) \\
\hline A3 & ability (6) & 2) begåvning (=having the skill to do something) \\
\hline A13 3 & resionation (5) & 1) avskedsansökan (=(an act or written statement of) quitting one's job \\
\hline A13 & resignation (S) & 2) undergivenhet (=submission to someone) \\
\hline & & 1) slå ned (=to destroy or bring to an end by force) \\
\hline A34 & suppress (5) & 2) dra in (=to prevent from being printed or made public) \\
\hline & & 3) hemlighålla (=to prevent from being shown) \\
\hline (1) & brood (5) & 1) ruva (=to sit on eggs) \\
\hline $\mathrm{A} 4 \mathrm{O}$ & Drood (j) & 2) grubbla (=to spend time thinking anxiously or sadly about something; worry or ponder) \\
\hline & & 1) tilltro (=belief or trust in the truth or rightness of something) \\
\hline A7 & credit (4) & 2) ära (=public approval or praise given to someone because of something they have done) \\
\hline At & & 3) kredit (=a system of buying goods or services and paying for them later) \\
\hline & & 4) poäng (=a completed unit of a student's work that forms part of a course, especially at a university) \\
\hline & & 1) skötsel (=management) \\
\hline & administration & 2) förvaltning (=management of the affairs of a business) \\
\hline A6 & & 3) regering (=the government) \\
\hline & & 4) utdelande (=the act of giving) \\
\hline
\end{tabular}




\begin{tabular}{|c|c|c|}
\hline $\mathrm{NO}$ & WORD & MEANINGS \\
\hline \multirow{3}{*}{ A32 } & \multirow{3}{*}{ idle (4) } & 1) sysslolös (=not working or operating productively) \\
\hline & & 2) lat (=disliking or avoiding activity or work) \\
\hline & & 3) utan mening (=having no particular purpose) \\
\hline \multirow{4}{*}{ A19 } & \multirow{4}{*}{ dealer (3) } & 1) -handlare (=a person in a stated type of business) \\
\hline & & 2) börsspekulant (=a person speculating on the stock exchange) \\
\hline & & 3) kortgivare (=a person handing out cards in a card game) \\
\hline & & 4) knarklangare (=a person selling drugs) \\
\hline \multirow{2}{*}{ A38 } & \multirow{2}{*}{ haul (3) } & 1) hala (=to pull with effort or difficulty) \\
\hline & & 2) transportera (=to carry (goods) in a vehicle, especially a truck \\
\hline \multirow{3}{*}{ A11 } & \multirow{3}{*}{ peak (2) } & 1) bergstopp (=a sharply pointed mountain top) \\
\hline & & 2) mösskärm (=the flat curved part of a cap which sticks out in front above the eyes) \\
\hline & & 3) höjdpunkt (=the highest point, level, etc., especially of a varying amount, rate, etc.) \\
\hline \multirow{3}{*}{ A15 } & \multirow{3}{*}{ wire (2) } & 1) ledning (=a piece of metal, usually covered with plastic, used for carrying electricity) \\
\hline & & 2) målsnöre (=a finishing tape in a race) \\
\hline & & 3) telegram (=(a piece of paper with) a message sent by telegraph \\
\hline \multirow{4}{*}{ A9 } & \multirow{4}{*}{ keen (2) } & 1) skarp (t. ex. kniv) (=sharp (e.g. knife)) \\
\hline & & 2) genomträngande (t. ex. vind) (=cold (e.g. wind)) \\
\hline & & 3) skarpsinnig (=(of the mind, the senses, the feelings, etc.) good, strong, quick at understanding, etc.) \\
\hline & & 4) ivrig (=(of a person) having a strong, active interest in something; eager to do something) \\
\hline \multirow{4}{*}{ A5 } & \multirow{4}{*}{$\begin{array}{l}\text { domestic } \\
\text { (1) }\end{array}$} & 1) hushålls- (=of or in the house or home) \\
\hline & & 2) hemkär (=enjoying home duties and pleasures) \\
\hline & & 3) inrikes (=of or within a particular country) \\
\hline & & 4) $\operatorname{tam}(=($ animal $)$ not wild but kept in a house or on a farm $)$ \\
\hline \multirow{4}{*}{$\mathrm{A} 2$} & \multirow{4}{*}{ director (1) } & 1) direktör (=a person who directs an organization) \\
\hline & & 2) regissör (=a person who instructs the actors, cameramen, etc. when making a film) \\
\hline & & 3) dirigent ( $=$ a person who directs an orchestra) \\
\hline & & 4) studierektor (=a person who is in charge of studies) \\
\hline \multirow{3}{*}{ A17 } & \multirow{3}{*}{ suit (1) } & 1) $\operatorname{kostym}(=a$ set of clothes made of the same material) \\
\hline & & 2) rättegång (=(an act of) hearing and judging a person, case, or point of law in a court) \\
\hline & & 3) färg i kortspel (=any of the four sets of cards used in games) \\
\hline \multirow{3}{*}{ A24 } & \multirow{3}{*}{ ugly (2) } & 1) ful (=unpleasant to look at; extremely unattractive) \\
\hline & & 2) otrevlig (=very unpleasant or threatening) \\
\hline & & 3) sur (=very sulky) \\
\hline \multirow{4}{*}{ A1 } & \multirow{4}{*}{ board $(0)$} & 1) bräda (=a long thin flat piece of wood) \\
\hline & & 2) anslagstavla (= a flat piece of hard material used to put or write things on) \\
\hline & & 3) kost (=(the cost of) meals \\
\hline & & 4) styrelse (=an official group that has responsibility for particular organization or activity) \\
\hline \multirow{4}{*}{ A8 } & & 1) lakan (=a large four-sided piece of usually cotton or nylon cloth used on a bed) \\
\hline & sheet $(0)$ & 2) platta (=a broad regularly shaped piece of glass or metal) \\
\hline & sheet $(0)$ & 3) ark (=a piece of paper) \\
\hline & & 4) tidning (=a newspaper) \\
\hline & & 1) kvadrat (=a shape with four straight equal sides forming four right angles) \\
\hline & & 2) torg (=a broad open area in a town) \\
\hline A16 & square (0) & 3) sjalett (=a piece of cloth to tie around your head) \\
\hline & & 4) vinkelhake (=a straight-edged often L-shaped tool for drawing and measuring right angles) \\
\hline & & $\begin{array}{l}\text { 1) charm (=a fine and attractive quality in movement or form, especially when this seems effortless and } \\
\text { natural) }\end{array}$ \\
\hline A25 & grace $(0)$ & 2) älskvärdhet (=willingness to behave in a fair and honourable way) \\
\hline & & 3) frist (=a delay allowed as a favour) \\
\hline & & 4) bordsbön (=a prayer before or after meals, giving thanks to God) \\
\hline
\end{tabular}




\begin{tabular}{|c|c|c|}
\hline NO & WORD & MEANINGS \\
\hline \multirow{4}{*}{ A27 } & \multirow{4}{*}{ needle $(0)$} & $\begin{array}{l}\text { 1) nål (=a long pointed metal pin with a hole in one end through which a piece of thread is passed, used in } \\
\text { sewing) }\end{array}$ \\
\hline & & $\begin{array}{l}\text { 2) spruta (=a thin hollow pointed tube, which is pushed into someone's skin to put a liquid (especially } \\
\text { medicine) into the body) }\end{array}$ \\
\hline & & 3) klippspets (=the top of a mountain) \\
\hline & & 4) obelisk (=a tall pointed stone pillar built usually in honour of a person or an event) \\
\hline \multirow{4}{*}{ A28 } & \multirow{4}{*}{ rude $(0)$} & 1) ohövlig (=(of a person or their behaviour) not at all polite; intentionally bad-mannered, offensive \\
\hline & & 2) obildad (=uneducated) \\
\hline & & 3) våldsam (=sudden and unpleasant) \\
\hline & & 4) primitiv (=simple and roughly made) \\
\hline \multirow{4}{*}{$\mathrm{A} 30$} & \multirow{4}{*}{ trunk (0) } & 1) trädstam (=the thick main stem of a tree) \\
\hline & & 2) bål (kroppsdel) (=the human body apart from the head and limbs) \\
\hline & & 3) koffert (=a large heavy case or box in which clothes or belongings are stored or packed for travel) \\
\hline & & 4) snabel (=the very long round nose of an elephant) \\
\hline \multirow{3}{*}{ A 31} & \multirow{3}{*}{ brow $(0)$} & 1) ögonbryn (=the hair above your eye) \\
\hline & & 2) panna (=the part of the face above the eyes and below the hair) \\
\hline & & 3) krön (=the upper part of a slope) \\
\hline \multirow{5}{*}{ A37 } & \multirow{5}{*}{ advance $(0)$} & 1) flytta framåt (=to move forward in position) \\
\hline & & 2) (be)främja (=to help, improve, or bring advantage to) \\
\hline & & 3) påskynda (=to bring forward to an earlier date or time) \\
\hline & & 4) lägga fram (=to introduce; suggest) \\
\hline & & 5) förskottera (=to provide (money) earlier than the proper or usual time) \\
\hline \multirow{5}{*}{ A39 } & \multirow{5}{*}{$\begin{array}{l}\text { discharge } \\
(0)\end{array}$} & 1) lasta av (=to unload) \\
\hline & & 2) avlossa (=to fire or shoot) (a gun, arrow, etc.)) \\
\hline & & 3) ladda ur (=to lose stored electrical power) \\
\hline & & 4) avsöndra (=to pour or let out) (gas, liquid, etc.)) \\
\hline & & 5) frige (=to allow or tell (a person) to go \\
\hline
\end{tabular}


The correct meanings of the Swedish polysemous words and their translation into English.

\begin{tabular}{|c|c|c|}
\hline NO & "WORD & MEANINGS \\
\hline \multirow{2}{*}{ A19 } & \multirow{2}{*}{ greppa (14) } & 1) ta tag i (=take (a) hold of) \\
\hline & & 2) begripa (=comprehend) \\
\hline \multirow{2}{*}{ A26 } & \multirow{2}{*}{ krasch (14) } & 1) skräll (=bang, crash) \\
\hline & & 2) våldsam sammanstötning (=violent encounter) \\
\hline \multirow{2}{*}{ A24 } & \multirow{2}{*}{ dragningskraft (13) } & 1) gravitation (=gravitation) \\
\hline & & 2) charm (=charm) \\
\hline \multirow{2}{*}{ A12 } & \multirow{2}{*}{ platt (13) } & 1) slät (=even, flat) \\
\hline & & 2) intetsägande (=empty (e.g. conversation), insipid) \\
\hline \multirow{2}{*}{ A13 } & \multirow{2}{*}{ samsas (13) } & 1) komma överens (=get on (well together)) \\
\hline & & 2) i sämja dela utrymme (=share space without any trouble) \\
\hline \multirow{2}{*}{ A29 } & \multirow{2}{*}{ huvudbry (13) } & 1) bekymmer (=worry) \\
\hline & & 2) gåta (=conundrum) \\
\hline \multirow{3}{*}{ A25 } & \multirow{3}{*}{ revolutionerande(13) } & 1) omstörtande (=subversive) \\
\hline & & 2) upprorisk (=rebellious) \\
\hline & & 3) nydanande (=innovative) \\
\hline \multirow{2}{*}{ A11 } & \multirow{2}{*}{ atmosfär (13) } & 1) luft (=air) \\
\hline & & 2) stämning (=atmosphere) \\
\hline \multirow{3}{*}{ A27 } & \multirow{3}{*}{ begrava (12) } & 1) jordfästa (=read the funeral service over) \\
\hline & & 2) täcka (=cover) \\
\hline & & 3) dra ett streck över (=draw a line across) \\
\hline & & 1) omvänd (=converted) \\
\hline A31 & frälst (10) & 2) såld på något (=be sold on) \\
\hline & & 3) räddad (=saved) \\
\hline 18 & (10) & 1) överlämnande (=handing over) \\
\hline A 8 & remiss (10) & 2) hänvisning (=referral) \\
\hline & & 1) hastigt avsluta (=finish abruptly) \\
\hline A9 & avbryta (9) & 2) göra en paus (=take a break) \\
\hline & & 3) snäsa av (=snub) \\
\hline & & 1) bestört (=perplexed) \\
\hline A4 & tagen (9) & 2) gripen (=arrested, taken, seized) \\
\hline & & 3) utmattad (=exhausted) \\
\hline & & 1) hälsa (=nod) \\
\hline A21 & nicka (9) & 2) skalla (=head) (verb) \\
\hline & & 3) slumra till (=doze off) \\
\hline & & 1) svalg (=throat) \\
\hline A22 & gap (8) & 2) öppning (=opening) \\
\hline & & 3) tomrum (=void) \\
\hline 17 & fiktion ( & 1) inbillning (=imagination) \\
\hline All & T1kt1on $(8)$ & 2) skönlitteratur (=fiction) \\
\hline & & 1) gråta (=cry) \\
\hline A37 & grina (7) & 2) grimasera (=grimace) \\
\hline & & 3) skratta (=laugh) \\
\hline & & 1) välljud (=euphony) \\
\hline A15 & harmoni (6) & 2) överensstämmelse (=concordance) \\
\hline & & 3) sinnesro (=tranquillity of mind) \\
\hline & & 1) avdunstande (=evaporating) \\
\hline & & 2) obeständig (=transient) \\
\hline A33 & flyktig (5) & 3) ytlig (=superficial) \\
\hline & & 4) snabb (=swift) \\
\hline A30 & darra (5) & 1) skaka (=tremble) \\
\hline & & 2) rysa (=shiver, shudder) \\
\hline & & 3) flimra (=flicker) \\
\hline & & 4) vibrera (=vibrate) \\
\hline A1 & börja (4) & 1) sätta igång (=get started) \\
\hline & & 2) ta sin början (=begin) \\
\hline & & 3) tillträda (=take office) \\
\hline & & 4) grunda (=establish) \\
\hline & & 5) ta första steget (=take the first step) \\
\hline
\end{tabular}




\begin{tabular}{|c|c|c|}
\hline $\mathrm{NO}$ & WORD & MEANINGS \\
\hline \multirow[t]{4}{*}{ A7 } & \multirow[t]{4}{*}{ skugga (4) } & 1) obelyst plats (=a place in the shadow) \\
\hline & & 2) blek avbild (=not a very good copy) \\
\hline & & 3) skepnad (=phantom, figure) \\
\hline & & 4) ständig följeslagare (=constant companion) \\
\hline \multirow[t]{2}{*}{ A38 } & \multirow[t]{2}{*}{ teknikalitet (4) } & 1) teknisk detalj (=technical detail) \\
\hline & & 2) formalitet (=formality) \\
\hline \multirow[t]{4}{*}{ A2 } & \multirow[t]{4}{*}{ ersättning (3) } & 1) kompensation (=compensation) \\
\hline & & 2) betalning (=payment) \\
\hline & & 3) gengäld (=in return) \\
\hline & & 4) reserv (=substitute) \\
\hline \multirow[t]{3}{*}{ A32 } & \multirow[t]{3}{*}{ fullfjädrad (3) } & 1) flygfärdig (=(fully) fledged) \\
\hline & & 2) erfaren (=experienced) \\
\hline & & 3) tvättäkta (=genuine, true) \\
\hline \multirow[t]{4}{*}{ A35 } & \multirow[t]{4}{*}{ herravälde (2) } & 1) makt (=power) \\
\hline & & 2) överhand (=the upper hand) \\
\hline & & 3) dominans (=dominance) \\
\hline & & 4) kommando (=command) \\
\hline \multirow{4}{*}{ A20 } & \multirow{4}{*}{ brunn (1) } & 1) vattenhål (=water-hole) \\
\hline & & 2) fontän (=fountain) \\
\hline & & 3) kurort (=health resort) \\
\hline & & 4) schakt (=shaft) \\
\hline \multirow[t]{4}{*}{ A28 } & \multirow[t]{4}{*}{ dirigera (1) } & 1) vara chef över (=be the manager of) \\
\hline & & 2) leda uppförandet av (=be in charge of the building, construction, erection, etc of) \\
\hline & & 3) ge riktning åt (=direct) \\
\hline & & 4) skicka (=send) \\
\hline \multirow[t]{4}{*}{ A34 } & \multirow[t]{4}{*}{ avig (1) } & 1) bakfram (=the wrong way round) \\
\hline & & 2) ovillig (=unwilling) \\
\hline & & 3) klumpig (=awkward) \\
\hline & & 4) befängd (=absurd) \\
\hline \multirow[t]{3}{*}{ A39 } & \multirow[t]{3}{*}{ krafsa (1) } & 1) skrapa (=scrape) \\
\hline & & 2) klottra (=doodle) \\
\hline & & 3) klösa (=scratch) \\
\hline \multirow[t]{3}{*}{ A6 } & \multirow[t]{3}{*}{ marginal (1) } & 1) kant (=border, edge, verge) \\
\hline & & 2) spelrum (=scope) \\
\hline & & 3) reserv (=reserve) \\
\hline \multirow[t]{2}{*}{ A36 } & \multirow[t]{2}{*}{ arbetsam (1) } & 1) flitig (=hard-working, industrious) \\
\hline & & 2) tröttsam (=tiresome) \\
\hline
\end{tabular}




\begin{tabular}{|c|c|c|}
\hline $\mathrm{NO}$ & WORD & MEANINGS \\
\hline \multirow{4}{*}{ A3 } & \multirow{4}{*}{ tillfälle $(0)$} & 1) händelse (=event, occurrence) \\
\hline & & 2) tidpunkt (=moment) \\
\hline & & 3) erbjudande (=offer) \\
\hline & & 4) möjlighet (=chance) \\
\hline \multirow{4}{*}{ A5 } & \multirow{4}{*}{ dryg $(0)$} & 1) överlägsen (=haughty) \\
\hline & & 2) varaktig (=lasting) \\
\hline & & 3) riklig (=abundant) \\
\hline & & 4) tidsödande (=time-consuming) \\
\hline \multirow{5}{*}{ A10 } & \multirow{5}{*}{ element $(0)$} & 1) beståndsdel (=component) \\
\hline & & 2) grundämne (=element (e.g. gold)) \\
\hline & & 3) värmekälla (=source of heat) \\
\hline & & 4) väder och vind (=wind and weather) \\
\hline & & 5) omgivning (=surroundings) \\
\hline \multirow{4}{*}{ A14 } & \multirow{4}{*}{ depression $(0)$} & 1) tryckt sinnesstämning (=low-spirited mood) \\
\hline & & 2) lågkonjunktur (=recession) \\
\hline & & 3) dalgång (=long(ish) valley) \\
\hline & & 4) lågtryck (=low pressure (weather)) \\
\hline \multirow{3}{*}{ A16 } & \multirow{3}{*}{ jäsa (0) } & 1) höja sig (=rise) \\
\hline & & 2) koka inombords (=boil (person)) \\
\hline & & 3) kråma sig (=strut) \\
\hline \multirow{5}{*}{ A18 } & \multirow{5}{*}{ lukta $(0)$} & 1) sprida doft (=diffuse (scent)) \\
\hline & & 2) vädra (=scent) \\
\hline & & 3) andas in (=breathe in, inhale) \\
\hline & & 4) ha en anstrykning av (=have a touch of) \\
\hline & & 5) studera flyktigt eller ytligt (=browse) \\
\hline \multirow{4}{*}{ A23 } & \multirow{4}{*}{ koloni (0) } & 1) jordlott (=allotment) \\
\hline & & 2) nybygge (=colony) \\
\hline & & 3) utlandssvenskar (=a group of Swedish citizens living in the same area abroad) \\
\hline & & 4) sommarläger (=summer camp) \\
\hline \multirow{2}{*}{ A 40} & \multirow{2}{*}{ tetig $(0)$} & 1) besvärlig (=difficult) \\
\hline & & 2) underlig (=strange) \\
\hline
\end{tabular}

